\title{
Structural Basis of the Pore-Forming Toxin/Membrane Interaction
}

\author{
Yajuan $\mathrm{Li}^{1}$, Yuelong $\mathrm{Li}^{2}$, Hylemariam Mihiretie Mengist ${ }^{2}$, Cuixiao Shi ${ }^{1}$, Caiying Zhang ${ }^{2} \oplus$, Bo Wang ${ }^{1}$, Tingting $\mathrm{Li}^{1}$, \\ Ying Huang ${ }^{1}$, Yuanhong $\mathrm{Xu}{ }^{1, *}$ and Tengchuan Jin ${ }^{2, *}$ (i)
}

1 Department of Clinical Laboratory, the First Affiliated Hospital of Anhui Medical University, Hefei 230022, China; lyj106@126.com (Y.L.); scx5250@163.com (C.S.); wangbo@ahmu.edu.cn (B.W.); litingting_0725@126.com (T.L.); huangying_ah2007@sina.com (Y.H.)

2 Hefei National Laboratory for Physical Sciences at Microscale, Laboratory of Structural Immunology, CAS Key Laboratory of Innate Immunity and Chronic Disease, Division of Life Sciences and Medicine, School of Basic Medical Sciences, University of Science and Technology of China, Hefei 230027, China; ly101@mail.ustc.edu.cn (Y.L.); hylemariam@mail.ustc.edu.cn (H.M.M.); caiyingz@mail.ustc.edu.cn (C.Z.)

* Correspondence: xyhong1964@163.com (Y.X.); jint@ustc.edu.cn (T.J.); Tel.: +86-13505694447 (Y.X.); +86-17605607323 (T.J.)

\section{check for}

updates

Citation: Li, Y.; Li, Y.; Mengist, H.M.; Shi, C.; Zhang, C.; Wang, B.; Li, T.; Huang, Y.; Xu, Y.; Jin, T. Structural Basis of the Pore-Forming Toxin/Membrane Interaction. Toxins 2021, 13, 128. https://doi.org/ $10.3390 /$ toxins 13020128

Received: 26 October 2020

Accepted: 2 February 2021

Published: 9 February 2021

Publisher's Note: MDPI stays neutral with regard to jurisdictional claims in published maps and institutional affiliations.

Copyright: (C) 2021 by the authors. Licensee MDPI, Basel, Switzerland. This article is an open access article distributed under the terms and conditions of the Creative Commons Attribution (CC BY) license (https:/ / creativecommons.org/licenses/by/ $4.0 /)$.

\begin{abstract}
With the rapid growth of antibiotic-resistant bacteria, it is urgent to develop alternative therapeutic strategies. Pore-forming toxins (PFTs) belong to the largest family of virulence factors of many pathogenic bacteria and constitute the most characterized classes of pore-forming proteins (PFPs). Recent studies revealed the structural basis of several PFTs, both as soluble monomers, and transmembrane oligomers. Upon interacting with host cells, the soluble monomer of bacterial PFTs assembles into transmembrane oligomeric complexes that insert into membranes and affect target cell-membrane permeability, leading to diverse cellular responses and outcomes. Herein we have reviewed the structural basis of pore formation and interaction of PFTs with the host cell membrane, which could add valuable contributions in comprehensive understanding of PFTs and searching for novel therapeutic strategies targeting PFTs and interaction with host receptors in the fight of bacterial antibiotic-resistance.
\end{abstract}

Keywords: pore-forming toxin; structure; membrane interaction

Key Contribution: We reviewed the structural mechanisms of pore formation and host-pathogen interaction of PFTs; which could add valuable contributions in searching for novel therapeutic strategies targeting PFTs to fight infection.

\section{Introduction}

Plasma membrane acts as a semi-permeability barrier between the cell and the extracellular environment, and its integrity is essential for cell survival and sustainability. Therefore, disruption of the plasma membrane is considered to be one of the ancient cellkilling mechanisms by which bacteria invade humans. Pore-forming proteins (PFPs) are among such molecules that can alter membrane permeability, in which pore-forming toxins (PFTs) constitute the major class [1-3]. Killing target cells by PFTs is a common virulence mechanism in a wide range of pathogenic bacteria. As the largest class of bacterial toxins, PFTs are mainly produced, but not exclusively by pathogenic bacteria. However, PFPs have been identified in all kingdoms, especially in eukaryotes, as part of their immune system [2].

The remarkable feature of (and PFTs) is that they initially and generally fold into a water-soluble, monomeric structure. Upon binding to specific receptors (sugars, lipid, or proteins) in the membrane, PFPs (PFTs) then oligomerize to form transmembrane pores with refined architecture, which alter membrane permeability and induce several responses in target cells. PFPs produced by eukaryotic organisms damage the bacteria membrane by inducing complement membrane attack complex (MAC) while damaging malignant cell 
membrane using perforin [2]. The pore produced by PFTs alters membrane permeabilization which allows small molecules such as ATP, specific ions, or large molecules proteins to pass through. For example, in gram-negative bacteria, type III secretion systems allow the passage of effector molecules by perforating membrane. The $B$ subunits of $A B$ toxins allow the passage of A subunit $[4,5]$. Finally, pore formation in the membrane leads to cellular behavior alteration and cell death. The interaction of PFTs and the membrane contribute to bacterial growth and colonization from the host immune response.

An increasing number of related pore-forming toxins from pathogens are being studied. Demonstrating their structure and implications on host-pathogen interaction helps to clearly understand the disease mechanism. Here we reviewed the structural mechanisms of pore formation and host-pathogen interaction of PFTs at an atomic level, contributing developing novel therapeutic strategies to fight infection targeting PFTs and/or host receptors interaction.

\section{Structural Classification and Characterization of the Pore-Forming Toxins}

Based on the main secondary structure of the transmembrane motif, PFTs can be categorized as $\alpha$-PFTs that form $\alpha$-helical transmembrane pore and $\beta$-PFTs that form $\beta$-barrel pores. The $\alpha$-PFTs use amphipathic helices to construct pores in the target membrane, where $\beta$-PFTs use $\beta$-barrel to transverse the membrane. As described in Table 1 , nine subfamilies of PFTs have been identified. Distinct structural characteristics of the PFT family lead to different insertion mechanisms (Figure 1). Generally, the inactive form of PFTs is secreted as a soluble monomer, which then converts from a soluble state to a transmembrane form (Figure 2). The understanding of the fine membrane pore-formation process is still not entirely clear and needs special techniques to track pore formation kinetics.

Table 1. Classification and details of pore-formation specific for each PFT family members.

\begin{tabular}{|c|c|c|c|c|c|}
\hline PFT & Family & Receptor & PDB & Organisms & References \\
\hline \multicolumn{6}{|c|}{$\alpha$-PFT } \\
\hline Colicin A & Colicins & $\mathrm{IM} / \mathrm{OM}$ & $1 \mathrm{COL}$ & E. coli & [6] \\
\hline Colicin N & Colicins & IM/LPS-OM & $1 \mathrm{~A} 87$ & E. coli & [7] \\
\hline Colicin Ia & Colicins & $\mathrm{IM} / \mathrm{OM}$ & $1 \mathrm{CII}$ & E. coli & [8] \\
\hline Colicin E1 & Colicins & $\mathrm{IM} / \mathrm{OM}$ & $2 \mathrm{I} 88$ & E. coli & [9] \\
\hline Colicin B & Colicins & $\mathrm{IM} / \mathrm{OM}$ & 1RH1 & E. coli & [10] \\
\hline EquinatoxinII (EqtII) & Actinoporins & Sphingomyelin & 1IAZ & A. equina & [11] \\
\hline SticholysinII (StnII) & Actinoporins & Sphingomyelin & $1 G W Y$ & S. helianthus & [12] \\
\hline Fragaceatoxin C (FraC) & Actinoporins & Sphingomyelin & $\begin{array}{l}\text { 4TSL, } \\
\text { 4TSY }\end{array}$ & A. fragacea & [13] \\
\hline Hemolysin E (HlyE) & Cytolysin A & Cholesterol & $\begin{array}{l}\text { 1QOY, } 2 \mathrm{WCD}, \\
\text { 6MRT }\end{array}$ & E. coli & [14-16] \\
\hline $\begin{array}{l}\text { Non-hemolytic tripartite } \\
\text { enterotoxin (Nhe) }\end{array}$ & Cytolysin A & Cholesterol & $4 \mathrm{~K} 1 \mathrm{P}$ & B. cereus & [17] \\
\hline HaemolysinBL $(\mathrm{Hbl})$ & Cytolysin A & Cholesterol & 2NRJ & B. cereus & [18] \\
\hline YaxAB & Cytolysin A & & $\begin{array}{l}6 \mathrm{EK} 4, \\
6 \mathrm{EK} 7, \\
6 \mathrm{EK} 8, \\
6 \mathrm{EL} 1\end{array}$ & Y.enterolitica & [19] \\
\hline XaxAB & Cytolysin A & & 6GY6 & X. nematophila & [20] \\
\hline CAMP & CAMP & GPI-anchored proteins & $\begin{array}{l}5 \mathrm{H} 6 \mathrm{I} \\
6 \mathrm{JLC}\end{array}$ & $\begin{array}{l}\text { S. agalactiae } \\
\text { M. curtisii }\end{array}$ & {$[21,22]$} \\
\hline
\end{tabular}


Table 1. Cont.

\begin{tabular}{|c|c|c|c|c|c|}
\hline PFT & Family & Receptor & PDB & Organisms & References \\
\hline$\alpha$-hemolysin (HlyA) & RTX & $\beta 2$ integrin & \multicolumn{3}{|c|}{ E. coli } \\
\hline $\begin{array}{c}\text { Adenylate cyclase-hemolysin } \\
\text { toxin (CyaA) }\end{array}$ & RTX & - & $\begin{array}{c}2 \text { COL } \\
\text { SASDCK9 } \\
\text { SASDCL9 }\end{array}$ & B. pertussis & {$[23,24]$} \\
\hline MARTX & RTX & - & - & A. hydrophila & \\
\hline \multicolumn{6}{|c|}{$\beta$-PFT } \\
\hline$\alpha$-haemolysin (Hla) & Hemolysin & $\begin{array}{l}\text { PC/ADAM10/ } \\
\text { disintegrin }\end{array}$ & $\begin{array}{l}\text { 3M2L, } \\
\text { 3M4D, } \\
\text { 7AHL, } \\
\text { 4YHD, } \\
\text { 6U49, } \\
\text { 6U4P, } \\
6 \mathrm{U} 3 \mathrm{~T}\end{array}$ & S. aureus & [25-28] \\
\hline$\gamma$-hemolysin (Hlg) & Hemolysin & PC & $4 \mathrm{P} 1 \mathrm{Y}$ & S. aureus & [29] \\
\hline Leukocidin (HlgACB, LukED) & Hemolysin & $\begin{array}{l}\text { CCR5, CXCR1, CXCR2, } \\
\text { CCR2,C5aR, DARC }\end{array}$ & $\begin{array}{l}3 \mathrm{ROH}, \\
4 \mathrm{Q} 7 \mathrm{G}\end{array}$ & S. aureus & [30] \\
\hline Necrotic enteritis toxin B (NetB) & Hemolysin & Cholesterol & $4 \mathrm{H} 56$ & C. perfringens & [31] \\
\hline$\delta$ toxin & Hemolysin & $\begin{array}{c}\text { Monosialicganglioside } 2 \\
\left(\mathrm{G}_{\mathrm{M} 2}\right)\end{array}$ & 2YGT & C. perfringens & [32] \\
\hline Vibrio cholerae cytolysin (VCC) & Hemolysin & Glycoconjugates & 1XEZ & V. choleraes & [33] \\
\hline $\begin{array}{l}\text { Vibrio vulnificus } \\
\text { hemolysin (VVH) }\end{array}$ & Hemolysin & $\begin{array}{c}\text { gangliosides, } \\
\text { N-acetyl-D-galactosamine, } \\
\text { N-acetyl-D-lactosamine }\end{array}$ & $\begin{array}{l}\text { 4OWJ, 4OWK, } \\
\text { 4OWL }\end{array}$ & V. vulnificus & [34] \\
\hline$\alpha$-toxin & Aerolysin & GPI-anchored proteins & $1 \mathrm{KHO}$ & C. perfringens & [35] \\
\hline$\varepsilon$-toxin (Etx) & Aerolysin & HAVCR1, MAL & $\begin{array}{c}\text { 1UYJ, } \\
\text { 6RB9, 3ZJX }\end{array}$ & C. perfringens & [36-38] \\
\hline Aerolysin & Aerolysin & $\begin{array}{l}\text { GPI-anchored } \\
\text { proteins (CD52) }\end{array}$ & $\begin{array}{c}\text { 1PRE, 3COM, } \\
\text { 3C0N, 3C0O, } \\
\text { 5JZT }\end{array}$ & Aeromonas spp. & [39-41] \\
\hline Hydralysin (Hln) & Aerolysin & - & - & Cnidaria spp. & \\
\hline Enterotoxin (CPE) & Aerolysin & Claudin & 3ZIW & C. perfringens & [42] \\
\hline Lysenin & Aerolysin & Sphingomyelin & $\begin{array}{l}\text { 3ZXD, 3ZXG, } \\
\text { 3ZX7, 5EC5, } \\
\text { 5GAQ }\end{array}$ & E. fetida & [43-45] \\
\hline Hemolytic lectin (LSL) & Aerolysin & Carbohydrates & $2 \mathrm{YPF}$ & L. sulphureus & [46] \\
\hline Monalysin & Aerolysin & & $4 \mathrm{MKO}, 4 \mathrm{MJT}$ & P. entomophila & [47] \\
\hline Perfringolysin $\mathrm{O}(\mathrm{PFO})$ & CDCs & Cholesterol & $1 \mathrm{PFO}$ & C. perfringens & [48] \\
\hline Suilysin (SLY) & CDCs & Cholesterol & $3 \mathrm{HVN}$ & S. suis & [49] \\
\hline Intermedilysin (ILY) & CDCs & Cholesterol, CD59 & $\begin{array}{l}\text { 1S3R, 4BIK, } \\
\text { 5IMW, 5IMT }\end{array}$ & S. intermedius & [50-52] \\
\hline Listeriolysin (LLO) & CDCs & Cholesterol & $4 \mathrm{CDB}$ & L. monocytoge-nes & [53] \\
\hline Lectinolysin (LLY) & CDCs & Cholesterol, CD59 & 3LEI & S. mitis & [54] \\
\hline Anthrolysin O (ALO) & $\mathrm{CDCs}$ & Cholesterol & $3 \mathrm{CQF}$ & B. anthracis & [55] \\
\hline Streptolysin O (SLO) & CDCs & Cholesterol & $4 \mathrm{HSC}$ & S. pyogenes & [56] \\
\hline Pneumolysin (PLY) & CDCs & Cholesterol & $\begin{array}{c}\text { 4ZGH, } \\
\text { 5AOF, } \\
\text { 5LY6, } \\
\text { 5CR6, 5AOE }\end{array}$ & S. pneumoniae & {$[57-59]$} \\
\hline Vaginolysin (VLY) & CDCs & Cholesterol & $\begin{array}{l}\text { 5IMY, } \\
\text { 5IMT, } \\
\text { 5IMW }\end{array}$ & G. vaginalis & [50] \\
\hline
\end{tabular}


Table 1. Cont.

\begin{tabular}{|c|c|c|c|c|c|}
\hline PFT & Family & Receptor & PDB & Organisms & References \\
\hline Plu-MACPE & MACPF & - & 2QP2 & P. luminescens & [60] \\
\hline Bth-MACPE & MACPF & - & $3 \mathrm{KK} 7$ & B. thetaiotaomicron & [61] \\
\hline
\end{tabular}

PFT, pore-forming toxin; IM, bacterial inner membrane; OM, bacterial outer membrane; LPS, lipopolysaccharide; E. coli, Escherichia coli; A. equina, Actinia equina; S. helianthus, Stichodactyla helianthus; A. fragacea, Actinia fragacea; B. cereus, Bacillus cereus; Y. enterolitica, Yesinia enterolitica; X. nematophila, Xenorhabdus nematophila; CAMP, Christie, Atkins, and Munch-Petersen; GPI, glycosyl phosphatidyl inositol; S. agalactiae, Streptococcus agalactiae; M. curtisii, Mobiluncus curtisii; RTX, repeats-in-toxin; B. pertussis, Bordetella pertussis; MARTX multifunctional autoprocessing repeats-in-toxin; A. hydrophila, Aeromonashy drophila; PC, phosphatidylcholine; ADAM10, disintegrin and metalloproteinase domain-containing protein 10; S. aureus, Staphylococcus aureus; CCR5, CC-chemokine receptor type 5; CXCR1, CXC-chemokine receptor type 1; C5aR, C5a receptor; DARC, Duffy antigen receptor for chemokines; C. perfringens, Clostridium perfringens; V. cholerae, Vibrio cholerae; V. vulnificus, Vibrio vulnificus; HAVCR1, hepatitis A virus cellular receptor 1; E. fetida, Eisenia fetida; L. sulphureus, Laetiporus sulphureus; P. entomophila, Pseudomonas entomophila; CDC, cholesterol-dependent cytolysin; S. suis, Streptococcus suis; S. intermedius, Streptococcus intermedius; L. monocytogenes, Listeria monocytogenes; S. mitis, Streptococcus mitis; B. anthracis, Bacillus anthracis; S. pyogenes, Streptococcus pyogenes; S. pneumoniae, Streptococcus pneumonia; G. vaginalis, Gardnerella vaginalis; MACPF, membrane attack complex component/perforin; P. luminescensis, Photorhabdus luminescens; B. thetaiotaomicron, Bacteroides thetaiotaomicron; PDB for which some structural data are available for the monomer and/or pore state; the list of receptors for each toxin is not exhaustive; "-" means unknown.

A
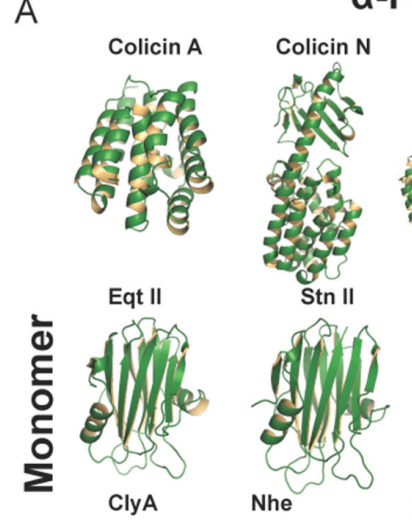

$\alpha-P F T$
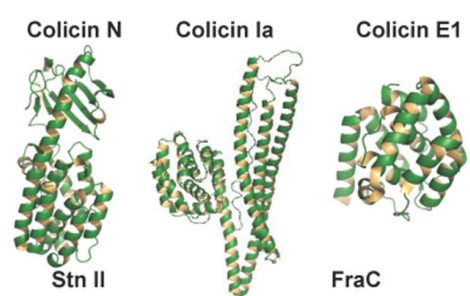

rac
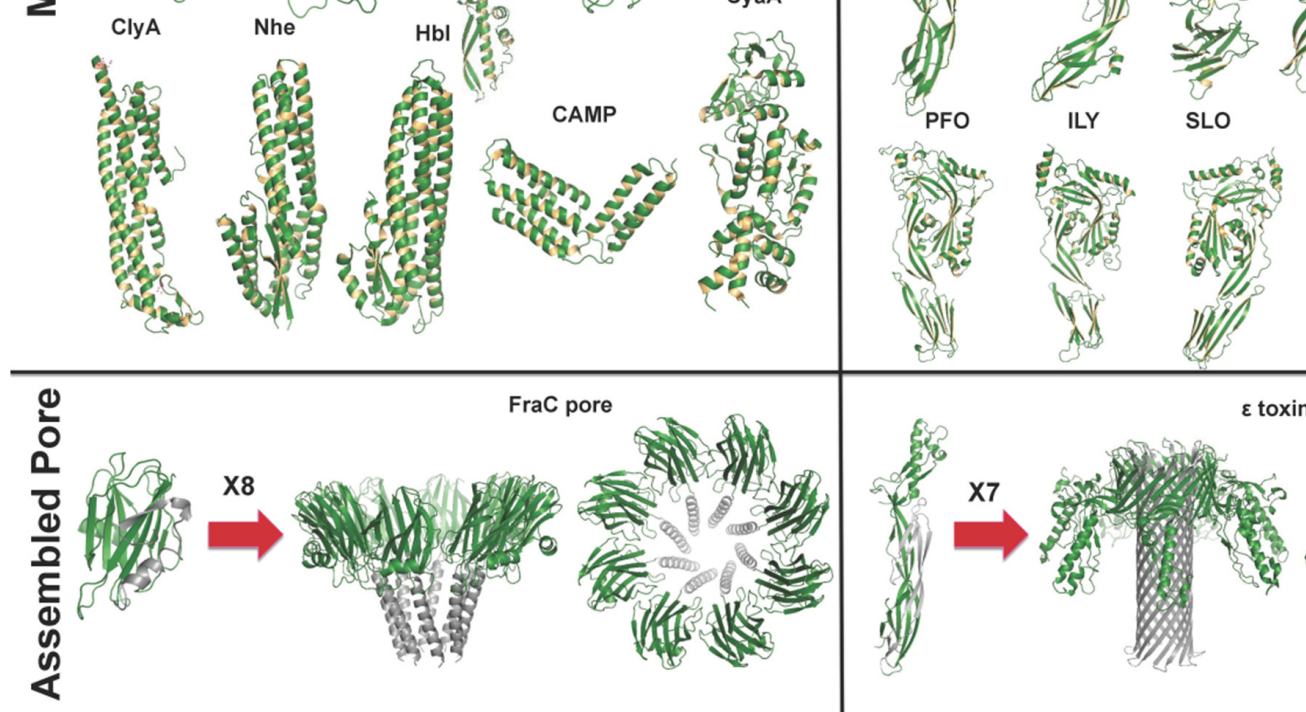

B

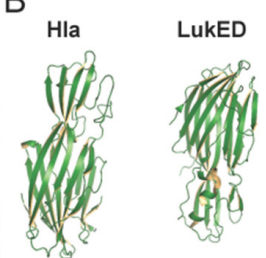

$\varepsilon$ toxin Aeolysin

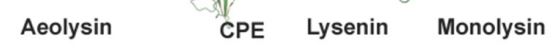

B-PFT
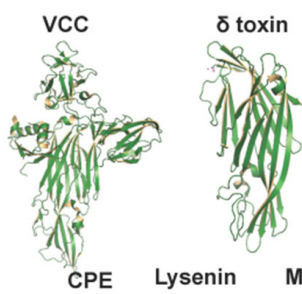

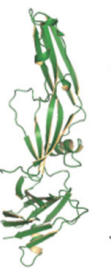

SLO
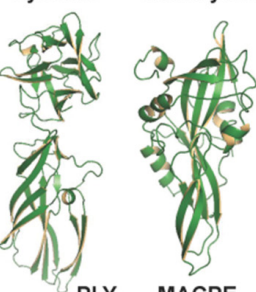

PLY MACPE
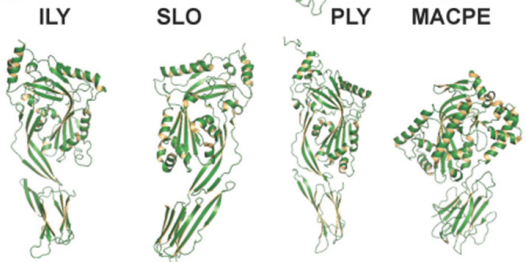

in pore

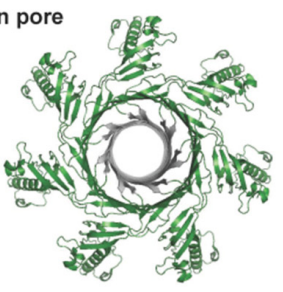

Figure 1. Structural characteristics of pore-formation specific for each structural family. Representative monomer and pore structure of $\alpha$-PFTs and $\beta$-PFT members are illustrated. For $\alpha$-PFTs, upon binding to the membrane, $\alpha$-helices undergo a conformational change to insert into the membrane and form membrane pore. For $\beta$-PFTs, monomer $\beta$-PFT first assembles in a pre-stem loop, and inserts into the membrane to form a partial $\beta$-barrel, and then combines with the other protomers to form a complete $\beta$-barrel. (A). $\alpha$-PFTs: soluble and membrane pore complex, adopted from PDBs 1COL, 1A87, 1CII, 2I88, 1IAZ, 1GWY, 4TSL, 1QOY, 4K1P, 2NRJ, 6JLC, 2COL, 4TSY. (B). $\beta$-PFTs: soluble and membrane pore complex, adopted from PDBs 4YHD, 4Q7G, 1XEZ, 2YGT, 1UYJ, 3C0M, 3ZIW, 3ZXD, 4MKO, 1PFO, 1S3R, 4HSC, 5AOF, 2QP2, 6 RB9. 


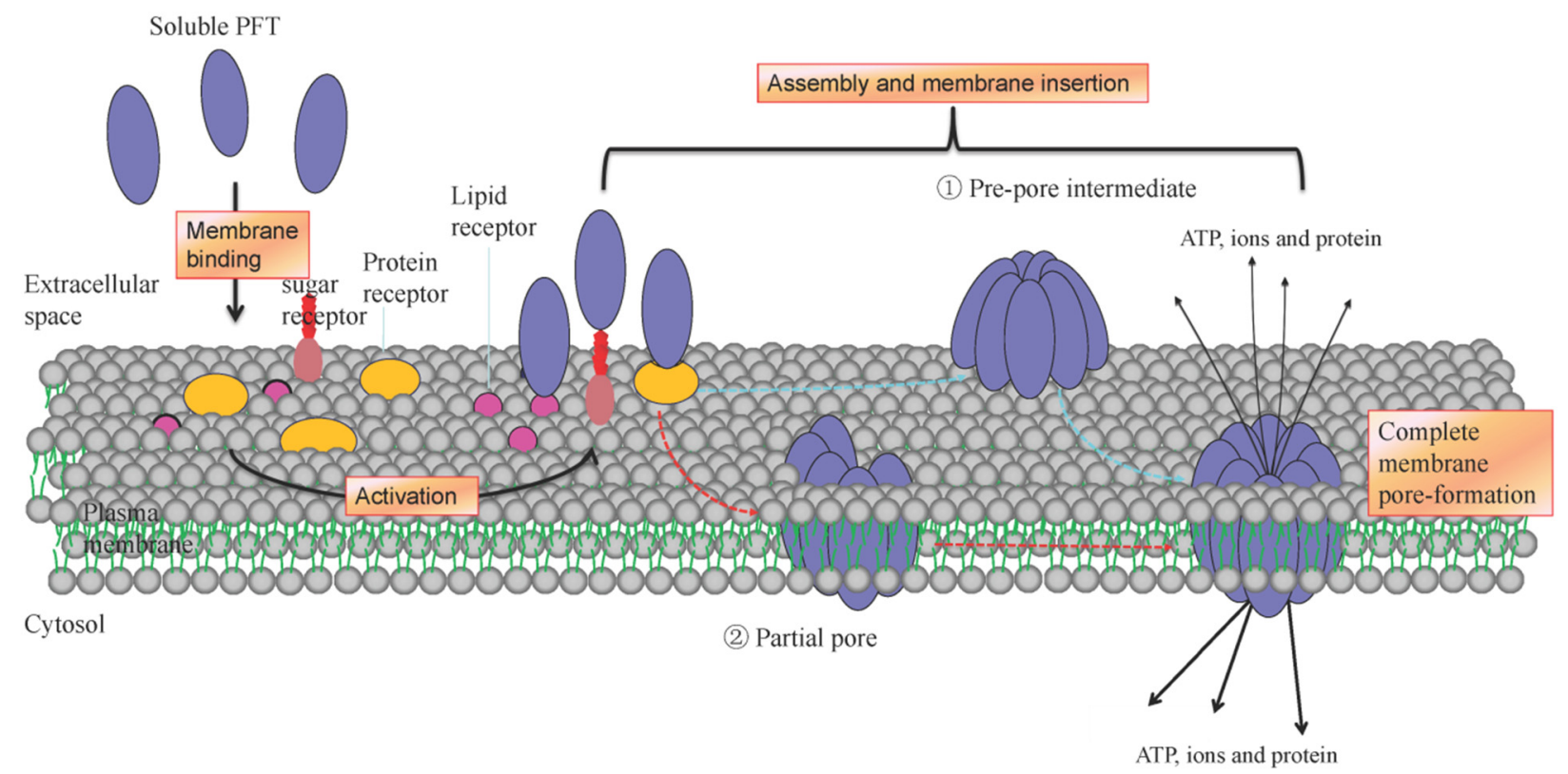

Figure 2. General mechanism of membrane pore formation by the bacterial PFTs. The diagram schematic presents the pore formation pathways of pore-forming toxins (PFTs). Soluble PFTs are recruited to the plasma membrane surface by binding to sugar, lipids or receptors molecules. The PFTs concentrate on the membrane surface, and then two pathways are alternatively taken to form the final membrane pore. In one pathway applicable to most $\beta$-PFTs, PFTs oligomerize on the membrane surface, and produce a pre-pore intermediate structure. In another pathway applicable to most $\alpha$-PFTs, PFTs oligomerize and insert into the plasma membrane coordinately by a mechanism of sequential oligomerization, which forms a partial pore or complete pores, and both are active. In both pathways of $\alpha$-PFT and $\beta$-PFT, formed transmembrane pores present distinct characteristics, and trigger cell responses.

\section{1. $\alpha$-PFTs Family}

The structures of many $\alpha$-PFTs have been determined by X-ray crystallography and electron microscopy. Among five $\alpha$-PFTs subfamilies, three subfamilies including colicin subfamily, cytolysin A subfamily and actinoporin subfamily, are the most studied PFTs; one subfamily of RTX family is $\alpha$-PFTs with limited knowledge; the last subfamily is CAMP, which was recently discovered and presents a unique structure. For some $\alpha$ PFTs, monomeric PFTs bind to the membrane in a step that precedes pore formation, and $\alpha$-helices are usually used to punch pores and insert into the membrane.

\subsubsection{The Colicin Subfamily}

Colicins are typical $\alpha$-PFTs and are generally produced by and toxic to Escherichia coli (E. coli). In E. coli strains, 25 different colicin members have been identified, among which colicins E1, A, B, N, Ia, Ib, K, 5, 10 are pore-forming colicins [62]. These PFTs are used to selectively eradicate other bacterial populations in the microbial community by punching holes in the inner membranes of these bacteria [63]. The first PFT structure described was colicin A, presenting a unique model for helices inside-out folded when inserted into lipid bilayers. The smallest pore-forming colicin is colicin N. These membrane pore-forming motifs of colicin consist of a bundle of $\alpha$-helices. It was reported that during the pore formation, except colicin A, colicin E and Ia also results in an "umbrella" conformation with oligomerized dimers or higher-order assemblies, which was shown by electron paramagnetic resonance (EPR) spectra [64]. Moreover, combined with electrostatic binding to the surface and hydrophobic interaction, colicins finally form mature membrane pore. An earlier study suggested that some helices are buried within colicins and form a hydrophobic hairpin loop structure in soluble state. Upon spontaneously binding to the target membranes, the hydrophobic $\alpha$-helical hairpins are exposed to form the transmembrane 
umbrella-like pores and subsequently insert into the lipid bilayer of the membrane [65]. Meanwhile, the insertion of the hydrophobic hairpin also could activate protein polymerization. The low $\mathrm{pH}$ and negatively charged micro-environment at the membrane interface may trigger this unfolding event, forming a nonspecific voltage-dependent pore supported by single-molecule study [66], leading to membrane depolarization and ultimately cell death. The exact structure and stoichiometry of colicin pore needs further exploration.

Besides the E. coli toxin, other bacterial toxins and eukaryotic proteins also adapt the colicin-fold structure. For example, the diphtheria toxin mediates the pore formation by colicin-fold domain to facilitate the translocation of the catalytic subunit of the toxin across the endosomal membrane, and endosomal acidification triggers conformational changes of toxin domain and ultimately insertion into the cytoplasm [67]. Bacillus thuringiensis produced pore-forming insecticidal Cry toxin also exhibits colicin-fold [68], a homologous ancestry fold with colicins to form bacterial type III secretion systems [69]. In the apoptotic pathway of eukaryotes, a phage-derived pore-forming BAX and BCL-2 homologous antagonist/killer (BAK) proteins accumulate on the mitochondrial and conduct colicin-like structural folds to mediate cytochrome $\mathrm{c}$ release, leading to cell death [70].

\subsubsection{The Cytolysin a Subfamily}

The cytolysin A subfamily includes cytolysin A (ClyA, also known as HlyE, or SheA), non-hemolytic tripartite enterotoxin (Nhe), and the B component of hemolysin BL enterotoxin $(\mathrm{Hbl})$, constituting another distinct class of $\alpha$-PFTs [71]. Cytolysin A is produced by certain strains of E. coli, and homologs of ClyA are also produced by Salmonella enterica and Shigella flexneri. Another cytolysin A subfamily member, Nhe and $\mathrm{Hbl}$, is produced by Bacillus cereus. ClyA monomer structure and pore complexes have been determined [15]. Accordingly, large and remarkable conformational changes involving $80 \%$ of residues and unique pore-forming mechanisms are observed. In solution, monomer ClyA displays an elongated almost entirely $\alpha$-helical secondary structure, and a short hydrophobic $\beta$-tongue. Upon membrane interaction, the $\beta$-tongue detaches from the protein and approaches the cholesterol-rich membrane, triggering conformational changes and rearrangement of $\mathrm{N}$ terminal amphipathic $\alpha$-helices and leading to its insertion inside the membrane [15]. Moreover, twelve monomers oligomerize together to form a ring-like helical barrel pore $[14,15]$ (Figure 1A). The detergent digitonin can induce trimer-like intermediate oligomer of ClyA, even without the formation of mature pore. However, whether trimers are formed in the regular pore formation process needs to be further confirmed [16].

The members of the Cytolysin A subfamily adopt similar pore-formation mechanism although with various numbers of protomers composition. Cytolysin A subfamily contains single, two, and three-component members. E. coli ClyA contains a single component, and $\mathrm{Yax} \mathrm{AB}$ presents two-component. YaxAB from Yesinia enterolitica and XaxAB from Xenorhabdus nematophila have been determined to provide similar structure with ClyA but demonstrate low sequence identity [20,72]. In mature YaxAB pore, two-component proteins (bipartite PFTs) are arranged as ten symmetrical heterodimers showing a spoked rim from the top [19], while ХaxAB possesses 12-15 heterodimers. XaxA stabilizes and activates $\mathrm{XaxB}$, while $\mathrm{XaxB}$ is responsible for puncturing the membrane [20]. Except for single and bipartite PFTs, tripartite PFTs also have been solved; for example, $\mathrm{Hbl}$ is comprised of Hbl-L1, Hbl-L2, and Hbl-B proteins while Nhe is comprised of NheA, NheB, and NheC. However, the assembly mode of these tripartite ClyA subfamilies is unclear. Recently, another tripartite ClyA subfamily toxin, AhlABC, was identified in Aeromonas hydrophila (A. hydrophila), and it showed all three components were involved in causing maximum cell lysis. AhlC tetramer first disassembles into monomers to bind membrane and recruits AhlB. Then AhlB undergoes a large conformational change from $\beta$-tongue to an extended $\alpha$-helix and forms an active pore when binding AhlA [73]. Besides, there are differences in helix length among these PFT subfamily members. For example, the helix is much shorter in Nhe A, a component of the tripartite Nhe toxin [17], resulting in different of pore formation process. Formation of ClyA pore requires concentrated $\alpha$ - 
helices by a mechanism of circular oligomerization. Twelve monomers of ClyA oligomerize together and undergo large conformational changes to form a ring-like helical barrel pore [15].Another alternative and non-classical pore formation mechanism is that E. coli ClyA forms a soluble prepore within the outer membrane vesicles (OMVs) [74]. For Vibrio cholerae cytolysin (VCC), a hemolysin subfamily member also adopts a similar OMVmediated delivery mechanism [74]. However, this OMV-mediated toxin secretion and delivery system have not been well illustrated yet.

\subsubsection{The Actinoporin Subfamily}

Actinporins toxins are produced by sea anemones. These toxins represent another distinct subfamily of $\alpha$-PFTs. Actinporins toxin protein of venom can paralyze predators and guard themselves by punching pores in the target cell membrane. The actinporin subfamily, including equinatoxin II (EqtII), produced by Actinia equina, fragacea toxin C (FraC) produced by Actinia fragacea, and sticholysin I and II (Stn I and Stn II) produced by Stichodatyla helianthus have been well studied. These proteins are composed of a core structure with $\beta$-sandwich and two flanking with $\alpha$-helices. Upon binding to the lipid membrane by specific recognition of sphingomyelin (SM) or phase-separated lipid membranes, the N-terminal amphipathic helix detaches from the $\beta$-sandwich and inserts into the membrane lipid bilayer to form transmembrane function pore. Eventually, 3-4 monomers oligomerize on the membrane surface and simultaneously inserted into the membrane to form transmembrane pore with the membrane lipids rearrangement detected by differential scanning calorimetry and atomic force microscopy [75] but without a pre-pore intermediate state. Another atypical PFT with a similar $\beta$-sandwich structure with actinoporin of $\alpha$-PFTs is thermostable direct hemolysin (Tdh) produced by Vibrio parahaemolyticus [76,77]; Intra-protomer disulphide bond formation during Tdh folding/assembly process facilitate Tdh oligomerization. However, whether it is an $\alpha$-PFTs still unclear.

The pores stoichiometry formed by these actinoporin subfamily varies from tetramers, such as Eqt II [78] and Stn II [12] to octamer such as FraC [79]. X-ray crystal structures of FraC in the form of monomeric, dimeric and octameric have been determined. It illustrated that the octameric FraC pore is assembled with sphingomyelin at a ratio of 1:1. Here, sphingomyelin acts as a receptor and a cofactor to complete the assembly of the mature pore. Besides, the N-terminal amphipathic helix of FraC undergoes a conformational change near the protomer state in pores. FraC pore comprises eight protomers (Figure 1A) with the hydrophobic motif towards oligomer, and hydrophilic motif towards the pore. This $\alpha$-helical bundle structure suggested that actinoporin protomers might directly assemble into a pore conformation without a pre-pore intermediate state, although the mechanism of the actinoporin subfamily is not completely clear. In many $\alpha$-PFTs, it is coupled and synchronous events for oligomerization and membrane insertion to finally form transmembrane pore [80]. Hydrophobic residues located external lumen towards the membrane lipid, while hydrophilic residues located interior lumen towards water molecules.

\subsubsection{Other $\alpha$-PFT Families}

The structure and pore-formation mechanism of PFTs have been focused on and studied over several decades. Some unclassified PFTs orphans, such as the repeats-in-toxin (RTX) subfamily, represent a unique class of bacterial exoproteins possessing numerous glycine-rich repeat units $(\mathrm{G}-\mathrm{G}-\mathrm{X}-\mathrm{G}-(\mathrm{N} / \mathrm{D})-\mathrm{D}-\mathrm{X}-(\mathrm{L} / \mathrm{I} / \mathrm{V} / \mathrm{W} / \mathrm{Y} / \mathrm{F})-\mathrm{X})$ at the C-terminus of each protein. This subfamily includes $\alpha$-hemolysin (HlyA) from E. coli, Adenylate cyclasehemolysin (CyaA) from Bordetella pertussis [81], and the multifunctional autoprocessing repeats-in-toxin (MARTX) from A. hydrophila and other pathogens [82].These RTX motifs exhibit intrinsically elongated disordered coil in Apo state, while exhibit rigid fold in the calcium-binding state, which is involved in the calcium-dependent secretion process for unidirectional export through the secretory channel [83]. This conformation change applies to bacterial species producing RTX. The calcium-binding RTX domain of the adenylate 
cyclase toxin (CyaA), produced by Bordetella pertussis, requires sub-millimolar calcium concentrations to active CyaA toxins translocation across the plasma membrane [84].

In the RTX subfamily, the number of repeats is different among their subfamily members. These RTXs form a parallel $\beta$-roll conformation present by a mean of a right-handed spiral $[85,86]$. Other factors, such as membrane lipid composition and concentration, affect RTX toxin perturbations to membranes. Therefore, pore-formation by RTX toxins may be a complex dynamic process involving membrane remodeling. Studies describing the poreforming stoichiometry and mechanism by the RTX subfamily are limited and remained to be solved.

Christie, Atkins, and Munch-Petersen (CAMP) is another unique pore-forming toxin produced by Streptococcus uberis, Propionibacterium acnes, Streptococcus agalactiae, and Mobiluncus curtisii. Recently, the soluble form of CAMP structure from Streptococcus agalactiae and Mobiluncus curtisii was determined and they reveal a unique bacterial toxin [21,22]. This CAMP subfamily presents $\alpha$ - helices bundled with $\mathrm{N}$-terminal 5 and C-terminal 3-helix. However, its interaction with the membrane remains a challenge. CAMP may bind to the GPI anchored cell membrane's glycosyl moieties to promote CAMP N-terminus insertion into the membrane. The mechanism of CAMP toxin interaction with the target membrane needs further explored. Deciphering this mechanism will facilitate a better understanding of pore-formation and its co-hemolytic activity by this subfamily of PFTs.

\section{2. $\beta$-PFTs Family}

$\beta$-PFTs are secreted by a wide variety of pathogenic bacteria, and are more extensively studied for several decades. Among $\beta$-PFTs, three are the most studied PFTs, including hemolysins, aerolysins, cholesterol-dependent cytolysins (CDCs), and one is relatively homologous membrane attack complex/perforin (MACPF) subfamily. $\beta$-strands are responsible for form $\beta$-barrel and insert into the membrane. The hydrophobic residues of the transmembrane domain are away from the pore core, and towards membrane lipids.

\subsubsection{The Hemolysin Subfamily}

S. aureus PFTs contribute to pathogenesis in different ways by interacting with distinct surface proteins, particularly in the immune system leading to cell death and bacterial dissemination, including $\alpha$-hemolysin (Hla) with a single component assembling into heptameric pores and $\gamma$-hemolysin $\mathrm{AB}$ (HlgAB), $\mathrm{HlgCB}$, Panton-Valentine leukocidin (PVL), leukocidin ED (LukED), and leukocidin AB (LukAB or LukGH) with two components assembling into octameric pores with four copies of each subunit [87]. Besides, necrotic enteritis toxin B (NetB) and $\delta$-toxins from Clostridium perfringens [32], cytolysin from Vibrio cholera [88], and hemolysin from Vibrio vulnificus [34] are also the prominent members of hemolysin subfamily in the $\beta$-PFT, which oligomerize into small $\beta$-barrel pores.

Most hemolysin subfamily members have been crystallized in the soluble form or in the pore conformation, presenting structural characteristics of $\beta$-PFT families. For example, $S$. aureus hemolysins present a rather compact structure in solution, and the pre-stem domain composing of a three-stranded $\beta$-sheet is fastened by hydrogen bond and located against the protein core. Upon oligomerization, the pre-stem was released and detached from the protein core to generates a 14-stranded $\beta$-barrel by anti-parallel $\beta$-hairpin and neighboring hairpins, leading to a ring-like heptameric pre-pore structure. This outer hydrophobic domain of $\beta$-barrel spontaneously inserts into the membrane in a concerted manner to form transmembrane pores. Another possibility is that membrane insertion and amphipathic $\beta$-barrel formation are simultaneous events. The crystal structure of the VHH lectin domain showed a heptameric ring arrangement similar to VCC [34].

\subsubsection{The Aerolysin Subfamily}

A second subfamily of $\beta$-PFTs is the aerolysin subfamily (a $\beta$-PFTs). The first known member of the aerolysin subfamily, aerolysin, is produced by Gram-negative Aeromonas spp., and related subfamily members present in bacteria, plants, and eukaryotes and 
throughout all kingdom of life. For example, $\varepsilon$-toxin and enterotoxin produced by Clostridium perfringens, $\alpha$-toxin produced by Clostridium septicum, monalysin produced by Pseudomonas entomophila, parasporin produced by $B$. thuringiensis, enterolobin produced by Enterolobium contortisiliquum; lysenin from the earthworm, biomphalysin produced by the snail Biomphalaria glabrata; $\beta \gamma$-CAT from the frog Bombina maxima are also the members of the aerolysin subfamily. While bacterial a $\beta$-PFTs are involved in killing host cell or punching roles in other species, eukaryotic members of a $\beta$-PFTs play a role in defense against parasites or pathogens. In the aerolysin subfamily members, primary sequences are diverse; however, crystallographic studies have revealed remarkable structural similarities among aerolysins members, including $\varepsilon$-toxin, enterotoxin (CPE), $\alpha$-toxin, hemolytic lectin (LSL), hydralysin toxins, monalysin, and the lysenin toxins. This a $\beta$-PFTs subfamily was revealed and characterized to include a common structural fold consisting of two concentric $\beta$-barrels.

The aerolysin fold protein, abundant in $\beta$-structure, is multidomain although relatively small with molecular weights 30 and $60 \mathrm{kDa}$. Usually, a $\beta$-PFTs are composed of one or more N-terminal receptor-binding domains (RBDs) and C-terminal the pore-forming module (PFM). However, RBDs located at the C-terminus are also found, such as in lysenin and enterotoxin structure. There is an exception that monalysin produced by Pseudomonas entomophila exhibits globular single domain structure and lack the RBD [47]. Monalysin pro-pore forms a stable doughnut-like 18-mer complex with two disks, in which the membrane-spanning region is fully buried. This conformation is different from other $\beta$-PFTs that receptor-dependent for membrane interaction [47]. The structural PFM, essential for pore formation, is a common conserved feature of a $\beta$-PFTs while RBD shows sequence differences.

The aerolysin in solution presents highly elongated conformation. Aerolysin is initially synthesized as a protoxin with a C-terminal extension where it oligomerizes into a heptameric ring-like structure after cleavage of C-terminal peptide [39]. The intermediate pre-pore and mature pore structures of the aerolysin in the pore-forming process have been determined by combining X-ray crystallography and cryo-electron microscopy (CryoEM) [40]. In general, the monomers assemble into a pre-pore structure with heptameric oligomer docking on the membrane surface. Then the pre-stem loops refold into transmembrane amphipathic $\beta$-hairpins to form a $\beta$-barrel pore. Eventually, the pre-pore twists sideways to transit into the transmembrane pore by a swirling mechanism that is likely to be shared by other aerolysin subfamilies. During this period, it undergoes spectacular rearrangement of the aerolysin pre-pore from an inverted mushroom shape to a disk-like extracellular structure with a central $\beta$-barrel stem in the view of a top to the bottom [3]. Aerolysin pores composed of six to nine protomers are relatively small, with the diameter ranging from 1-4 $\mathrm{nm}$. A similar pore architecture was also observed in the hemolytic lectin CEL-III from Cucumaria echinata [89]. A recent study revealed another novel protein fold and pore-formation mechanism by aerolysin. The oligomerized monomer can form two highly stable concentric $\beta$-barrels with zipper-like. This aerolysin forms a final pore in a lipid bilayer by a mechanism of piston-like puncturing [39]. The pore-forming mode of aerolysin is shared with many other $\beta$-PFTs. But it still needs further investigation to confirm their interaction mechanism.

In membrane pore formation, amphipathic $\beta$-barrels are stabilized and they are fixed in position by a distinct mechanism. Charged residues of the transmembrane $\beta$-hairpin in S. aureus Hla and hydrophobic residues of transmembrane $\beta$-hairpins in aerolysin are responsible for anchoring the barrel preventing movement. The latter adopted a rivetlike configuration in the bilayer core. Furthermore, the $\beta$-barrels lumen of aerolysin is also full of charged residues, which is different from those in S. aureus Hla. Besides, Clostridium perfringens epsilon toxin (Etx, $\varepsilon$-toxin) is also a member of a $\beta$-PFTs. The overall structure of the Etx pore resembles aerolysin with the $\beta$-barrel spanning the height of the pore (Figure 1B). $\varepsilon$-toxin pore suggests conserved and concentric double $\beta$-barrel with heptameric oligomerization. It is also devoid of a vestibular region observed in the $\alpha$ - 
hemolysin subfamily, and the protomer consists of $\beta$-hairpin, cap, and RBD domain [36]. During pore formation, Etx monomer undergoes large conformational changes, among which $\beta$-hairpin with insertion loop unfolds to create the inner $\beta$-barrel while cap domain moves away from inner $\beta$-barrel.

\subsubsection{The Cholesterol-Dependent Cytolysin Subfamily}

The cholesterol-dependent cytolysin (CDC) subfamily is a large subfamily of $\beta$-PFTs, which form large oligomeric pore complexes responsible for disrupting cellular membranes $[90,91]$. This subfamily mostly produced by the Gram-positive bacteria, including perfringolysin O (PFO) of Clostridium perfringens [92], suilysin (SLY) of Streptococcus suis, streptolysin O (SLO) of Streptococcus pyogene, intermedilysin (ILY) of Streptococcus intermedius, listeriolysin O (LLO) of Listeria monocytogenes [53], anthrolysin O (ALO) of Bacillus anthracis [93], and pneumolysin (PLY) of Streptococcus pneumoniae.

The structures of CDCs have been determined by X-ray crystal, electron microscopy and AFM analysis. Different from hemolysin and aerolysin-like small $\beta$-PFT contributing single $\beta$-hairpin to form $\beta$-barrel pores, large pore-forming $\beta$-PFT, each CDC protomer contributes two amphipathic $\beta$-hairpins to transmembrane $\beta$-barrel. CDCs assembled into very large ring-like structures composing of around 30 to 50 protomers. However, the factors and mechanisms triggering the transmembrane pores are still not entirely clear. A conserved F/Y-F/Y-Xn-YGR motif with the CDCs is reported critical as the sensor to initiate the prepore-to-pore transition [94].

All CDCs have the same domain structure as shown by sequence comparison, and thus inserting into target membranes could be by the same way. PFO is an elongated $\beta$-sheet-rich multidomain protein, and the relatively stable interface between the D3 and D1, 2 play a key role in pore formation by PFO and even entire CDCs [95]. All CDCs are secreted, except pneumolysin, which is released after bacterial autolysis or antibiotic therapy. Pneumolysin (PLY) is another CDC, with typical characteristics. The structure of soluble monomer and ring-like PLY pore have been determined by X-ray diffraction [96] and cryo-EM, respectively, which illustrate the mechanism of membrane insertion and mature pore formation by time-lapse AFM [57]. Monomer PLY assemble into rings on the membrane surface side by side, then D3 helices refold and trigger the refold of the neighbor monomer. The unfolding $\beta$-hairpins traverse the hydrophobic membrane and merge into one large 168-strand $\beta$-barrel, which is irreversible.

In general, the monomer CDC presents a central $\beta$-sandwich flanking with two pairs of short $\alpha$-helices. Upon oligomerization, $\alpha$-helices undergo a drastic prion-like conformational transition from $\alpha$-helix-to $\beta$-strand. $80-200 \beta$-strands insert into the membrane to form a giant $\beta$-barrel. This mode of action is also observed in hemolytic lectin CEL-III of the sea cucumber [89]. By an oligomerization mechanism of sequential addition, CDCs produce not only absolute ring pores but also produce arc-like structures in the state of pre-pore, and both states are active, which was also confirmed for SLY [97]. Moreover, $\beta$-strands alignment is essential for membrane pore assembly and formation. In the pre-pore complex, $\beta$-hairpins are highly dynamic, while in the pore state, it exhibits a locked $\beta$-barrel, and $\beta$-strands produce a $20^{\circ}$ tilt to the membrane [98]. One study by AFM revealed that CDCs undergo conformational elongation on the membrane surface during the pre-pore-pore transition [99]. The CDC pre-pore transits to pore by undergoing a collapse. This process requires the tilting of $\beta$-strands to the membrane and the rotation of the toxin core domain by the swirling mechanism, which is also reported in aerolysin collapse [40]. A similar architecture was also observed for mammalian perforins and membrane attack complex components [91], suggesting these proteins may be ancient relatives. The understanding of the pore-forming mechanism of CDCs can also contribute to other relative proteins. Besides, during the process of pore-formation, membrane insertion may be accompanied by membrane lipid organization. More studies are warranted to reveal the mechanism for host-PFTs interactions at molecular levels. 


\section{Diversification of Interaction of PFTs with Membrane Components}

PFTs produced by different organisms target distinct host membrane by interacting with membrane sugar, lipids, and protein receptors or receptor-like molecules by recognizing specific structural motifs (Figure 2). Efficient interaction of PFT with cell membrane receptors is a critical initial step to drive PFTs self-assembly, the membrane pore formation and a subsequent array of signaling cascades and cellular responses [2]. In this process, PFTs first bind to the membrane to concentrate monomer PFTs on the membrane surface, facilitating the self-assembly and membrane insertion action of the PFT protomers.

Bacterial PFTs or PFPs that target bacteria often bind to glycans that covalently coupled membrane associated proteins or in the glycosyl phosphatidyl inositol (GPI) region. For example, VCC of hemolysin subfamily was shown to bind cell surface glycosylated proteins through $\beta$-trefoil and $\beta$-prism domain, among which $\beta$-prism can augment the binding of VCC to the cell membrane by surface glycans to facilitate further pore oligomerization and formation $[100,101]$. Another study indicated a sialoglycoprotein, glycophorin Bis a receptor for VCC [102]. VVH recognizes various cell surfaces by binding to different sugars such as glycerol, N-acetyl-D-galactosamine (GalNAc), and N-acetyl-D-lactosamine (LacNAc) [34], suggesting a versatile mode of recognition for VVH invading host cell. Aerolysin of aerolysin subfamily binds to the N-linked glycan and the GPI anchor on cell the membrane by its $\mathrm{N}$-terminal protruding domain of the protein core [103,104]. Besides, $\varepsilon$-toxin of aerolysin subfamily binds to hepatitis A virus cellular receptor 1 (HAVCR1), an O-linked glycoprotein [105]. In another receptor, the tetraspan membrane proteolipid myelin and lymphocyte protein (MAL), the second extracellular loopis critical for binding and cytotoxicity of $\varepsilon$-toxin [36]. Intermedilysin (ILY) of CDC subfamily binds to CD 59 on the human cells, which is a GPI-anchored protein [106]. CAMP subfamily toxins may also function through attaching to the GPI moiety on eukaryotic cell surfaces [21,107]. Colicin $\mathrm{N}$ of colicins subfamily first concentrates on the bacterial outer membrane by binding to lipopolysaccharides (LPS), then translocates to the inner membrane through porin proteins [108]. Besides, eukaryotic C-type lectins active immune response by binding to peptidoglycan carbohydrate of the gram-positive bacteria cell wall and oligomerize to form a hexameric membrane pore [109].

For membrane pore formation, some PFTs also prefer binding to lipids in the membrane and lipid type play an essential role in pore formation. In aerolysin subfamily, aerolysin has been revealed to bind to lipid rafts and lipid-anchored protein [110]. Lysenin specifically binds to sphingomyelin [111] abundant in lipid rafts. As a constitutive cofactor, sphingomyelin is involved in assembling the FraC pore of the sea anemone toxin [79]. The lipid-binding sites and lipid environments in this toxin modulate the affinity and specificity of membrane binding. In addition to glycosylated proteins and receptor binding, specific membrane lipids, including cholesterol and sphingolipid, can also regulate VCC's pore-forming activity [112,113], however, it did not show significant structural specificity in the toxin-cholesterol interaction. Vibrio cholerae cytolysin (VCC) binds nonspecifically to membrane lipid bilayer via amphipathicity-driven partitioning and bind specifically to membrane phospholipid head group via VCC motif [113].

Cholesterol, another lipid abundant in lipid rafts, mediates CDCs oligomerization in lipid raft-like domains. Cholesterol is required for CDCs cytolytic activity. In CDC subfamily, PFO is extensively used to study the interaction of CDCs with membranes. The PFO oligomerization and pore formation depends on the host membrane's cholesterol concentration. The composition and arrangement of membrane lipid is important to CDC pore formation [114]. It was reported that the lipid environment is critical for the interaction of LLO with cholesterol through 19F-NMR spectroscopy [115]. Such that pore formation regulation is achievable by changing the lipid composition. In specific membrane environments, the structure of L3 and possibly L2 of CDCs can facilitate the optimal binding of different CDCs [116]. The conserved undecapeptide ECTGLAWEWWR and threonineleucine pair among CDC provides the key motifs for membrane binding [117] and PFO pore formation [118]. In addition to lipid rafts, lipids themselves can directly regulate membrane 
pore formation. For example, E. coli colicins of $\beta$-PFT showed an anionic lipid, cardiolipin, in the bacterial inner membrane [64], promoting the umbrella pore conformation.

In addition to sugars and lipids, some specific protein receptors of PFTs have been identified. For example, a disintegrin and metalloprotease 10 (ADAM10) could be a protein receptor that has high affinity for S. aureus $\alpha$-hemolysin (Hla) and enables cytotoxic activity target to epithelial cells [119]. Cry, a biological insecticide produced by Bacillus thuringiensis binds on its receptor aminopeptidase $\mathrm{N}$ and cadherin-like proteins. Besides, for the host immune system, PFTs targets distinct immune cells by binding specific receptors. PVL targets neutrophils, even monocytes, and macrophages by binding to the C5a receptor (C5aRs) [120]. CD31 or PECAM-1 on endothelial cells is the specific membrane receptor for Clostridium perfringens $\beta$-toxin and essential for interaction [121]. In most cases, cholesterol on the target membranes has been shown as the receptor for the CDCs. Specific structural motifs of CDCs are responsible for recognizing and binding to cholesterol receptors. In other cases, intermedilysin (ILY) of CDCs, bind to CD59 receptor (a GPI-anchored protein) [106], in which cholesterol is not the direct receptor but still required to form membrane pore. The ILY crystals have been recently determined in soluble monomer and complex with human CD59 receptor, which defines two distinct interfaces. It also revealed that ILY-derived peptide inhibits pore formation through interfering binding between ligand and receptor [50,51]. Vaginolysin (VLY), a CDC produced by Gardnerella vaginalis, can bind to both CD59 and cholesterol as receptors [122]. In fact, CDCs bind glycan and cholesterol independently.

These characterizations of PFTs provide insight into that structure-guided design of PFTs-binding peptides and disruption of interaction with their target membrane components, offering a promise for therapeutic development.

\section{Anti-Infection Therapeutic Strategies and Application Targeting PFTs}

PFTs of most pathogenic bacteria's ability to invade host makes it an attractive target for developing potent drugs that can withstand the acquired resistance observed in the conventional antimicrobial therapy.

The growing illumination of the structure and function of PFTs helps to develop antimicrobial drugs by targeting these proteins or their interaction with membrane receptors. Based on conformational rearrangements in PFTs during pore formation, it offers ways of screening small compounds; for example, Oroxylin A can inhibit the hemolytic activity of Hla by hindering the transmembrane pore assembly [123]. The soluble ntetradecylphosphocholine (C14PC) compound can protect human immune cells against lysis by PVL and $\alpha$-toxin [25]. Theoretically, these compounds can be used in the treatment of multidrug-resistant S. aureus infections. Furthermore, DNA aptamers, as a novel strategy, can also target S. aureus $\alpha$-toxin [124]. Quercetin as a promising therapeutic candidate alleviated cytotoxicity by targeting SLY and subsequent inflammation for Streptococcus suis infection [125].

Given the specific binding of PFTs to receptors, synthetic GPI molecules and GPI analogs can inhibit pore assembly [126]. Also, by a similar mechanism, therapeutic antibodies have potential roles in hindering pore formation. It was reported in both nondiabetic and diabetic mice model, neutralization of $\alpha$-toxin with anti- $\alpha$-toxin monoclonal antibody had a therapeutic effect on S. aureus-infected injury [127]. Targeting of PFTs provides a novel therapeutic approach for bacterial infections. Similarly, the receptor could also be targeted. For example, CCR5 antagonist, maraviroc, blocks LukED-dependent cell death and confers resistance to $S$. aureus infection in CCR5-deficient mice model [128]. P2XRreceptor antagonist also prevented Hla-induced lysis by interfering with its interaction with membranes [129]. However, this approach targeting receptors as a therapeutic strategy is impractical as it may harm the immune system.

Developing recombinant toxoid vaccines by targeting PFTs is another strategy to reduce the toxicity of PFT and trigger immune responses. Based on toxin and pore structure, it is feasible to design attenuated vaccine by mutation, such as variants of NetB [130] 
and $\varepsilon$-toxin [131]. Recombinant leukocidin domain of Vibrio vulnificus hemolysin A was an effective toxoid to protect against Vibrio vulnificus in a mouse model [132]. In addition, S. pneumoniae Ply of the CDC subfamily has been targeted to develop promising pneumolysoid candidates, including $\triangle 6 \mathrm{PLY}$ mutant [133] and PsaA [134] and CbpA [135]. Recent two PLY mutant $\mathrm{PLY}_{\mathrm{D} 168 \mathrm{~A}}$ and $\mathrm{PLY}_{\Delta 146 / 147}$ by interfering with monomer refold and membrane insertion were reported no hemolytic activity, the later also can not bind to the membrane. These amino acid sites play a important role in ionic interaction between $\beta$-strands to stabilize the pore complex [57]. Nanotoxoid vaccines combining the non-toxic PFTs with antigen presentation, may have potential value infighting against antibiotic-resistant infections. For example, S. auerus Hla pores nanotoxoid triggers an effective immune response in vivo [136]. Biomimetic nanoparticles inhibit the cytotoxic effects of GBS $\beta$-hemolysin/cytolysin [137].

The Cry34Abl/Cry35Abl Cry toxin from Bacillus thuringiensis have been introduced to corn hybrids to provide protection from the western corm rootworm feeding via a pore forming mechanism [138]. Finally, the effect of pore formation on cell death can be applied as an interesting suicide gene therapy in tumor cells by transfecting the PFT into cancer cell lines. For example, moxetumomabpasudotox-tdfk (LUMOXITI ${ }^{\circledR}$, AstraZeneca Pharmaceuticals LP), animmunotoxin chimeric composed of a pore-forming domain of Pseudomonas exotoxin A and an antibody that is responsible for targeting cell, has been approved for application in B-cell cancer by the FDA in 2018 [139].

\section{Conclusions}

PFT is a widespread virulence factor of pathogenic bacteria. Final results of pore formation modulate or kill host cells, leading to bacterial dissemination and growth. Extensive studies provide a general model of actions of diverse PFTs. Inactive, soluble PFTs undergo a conformation change to form mature and sophisticated transmembrane pores on the target cell membrane, although each of the PFT families has distinct structural folding and pore formation mechanism. Different members within specific PFT subfamily ( $\alpha$-PFTs and $\beta$-PFTs) have distinct structural features. Therefore, PFTs from distinct subfamilies sometimes mediate similar functional consequences. Furthermore, identifying PFTs receptor in membrane lipids, sugars, and proteins reveal specific interaction between host and pathogens. In summary, elucidating these structure mechanisms of membrane pore formation enables the designing of therapeutics including antibodies, drugs, peptides or nanotoxoids, and subsequent infection, particularly for multi-drug resistant strains.

The structural characterization of monomer PFTs and their identified membrane pore has increased the understanding of PFTs to some extent. However, more studies are required to explore further the membrane pore complexes and kinetic processes of pore formation to further reveal the implication of the PFTs for host-pathogen interaction.

Author Contributions: Y.L. (Yajuan Li) wrote original draft; Y.L. (Yuelong Li) and C.Z. revised figures; H.M.M., C.S., B.W., T.L., Y.H., Y.X. and T.J. reviewed and edited the manuscript; Y.X. and T.J. provided funding. All authors have read and agreed to the published version of the manuscript.

Funding: This research was funded by the Strategic Priority Research Program of the Chinese Academy of Sciences (Grant No. XDB29030104), the National Natural Science Foundation of China (Grant No.: 31870731, 31971129), the Fundamental Research Funds for the Central Universities, and the Emergency Research and Public Relations Project of Anhui Medical University (Grant No.: YJGG202002).

Institutional Review Board Statement: Not applicable.

Informed Consent Statement: Not applicable.

Data Availability Statement: Not applicable.

Conflicts of Interest: The authors declare no conflict of interests. 


\section{References}

1. Gonzalez, M.R.; Bischofberger, M.; Pernot, L.; van der Goot, F.G.; Freche, B. Bacterial pore-forming toxins: The (w)hole story? Cell. Mol. Life Sci. 2008, 65, 493-507. [CrossRef] [PubMed]

2. Bischofberger, M.; Iacovache, I.; Van der Goot, F.G. Pathogenic pore-forming proteins: Function and host response. Cell Host Microbe 2012, 12, 266-275. [CrossRef]

3. Dal Peraro, M.; van der Goot, F.G. Pore-forming toxins: Ancient, but never really out of fashion. Nat. Rev. Microbiol. 2016, 14, 77-92. [CrossRef] [PubMed]

4. Park, D.; Lara-Tejero, M.; Waxham, M.N.; Li, W.; Hu, B.; Galan, J.E.; Liu, J. Visualization of the type III secretion mediated Salmonella-host cell interface using cryo-electron tomography. eLife 2018, 7. [CrossRef]

5. Fowler, C.C.; Stack, G.; Jiao, X.; Lara-Tejero, M.; Galan, J.E. Alternate subunit assembly diversifies the function of a bacterial toxin. Nat. Commun. 2019, 10, 3684. [CrossRef]

6. Parker, M.W.; Postma, J.P.; Pattus, F.; Tucker, A.D.; Tsernoglou, D. Refined structure of the pore-forming domain of colicin A at 2.4 A resolution. J. Mol. Biol. 1992, 224, 639-657. [CrossRef]

7. Vetter, I.R.; Parker, M.W.; Tucker, A.D.; Lakey, J.H.; Pattus, F.; Tsernoglou, D. Crystal structure of a colicin N fragment suggests a model for toxicity. Structure 1998, 6, 863-874. [CrossRef]

8. Wiener, M.; Freymann, D.; Ghosh, P.; Stroud, R.M. Crystal structure of colicin Ia. Nature 1997, 385, 461-464. [CrossRef] [PubMed]

9. Elkins, P.; Bunker, A.; Cramer, W.A.; Stauffacher, C.V. A mechanism for toxin insertion into membranes is suggested by the crystal structure of the channel-forming domain of colicin E1. Structure 1997, 5, 443-458. [CrossRef]

10. Hilsenbeck, J.L.; Park, H.; Chen, G.; Youn, B.; Postle, K.; Kang, C. Crystal structure of the cytotoxic bacterial protein colicin B at 2.5 A resolution. Mol. Microbiol. 2004, 51, 711-720. [CrossRef]

11. Athanasiadis, A.; Anderluh, G.; Macek, P.; Turk, D. Crystal structure of the soluble form of equinatoxin II, a pore-forming toxin from the sea anemone Actinia equina. Structure 2001, 9, 341-346. [CrossRef]

12. Mancheno, J.M.; Martin-Benito, J.; Martinez-Ripoll, M.; Gavilanes, J.G.; Hermoso, J.A. Crystal and electron microscopy structures of sticholysin II actinoporin reveal insights into the mechanism of membrane pore formation. Structure 2003, 11, 1319-1328. [CrossRef]

13. Tanaka, K.; Caaveiro, J.M.; Morante, K.; Gonzalez-Manas, J.M.; Tsumoto, K. Structural basis for self-assembly of a cytolytic pore lined by protein and lipid. Nat. Commun. 2015, 6, 6337. [CrossRef]

14. Wallace, A.J.; Stillman, T.J.; Atkins, A.; Jamieson, S.J.; Bullough, P.A.; Green, J.; Artymiuk, P.J.E. coli hemolysin E (HlyE, ClyA, SheA): X-ray crystal structure of the toxin and observation of membrane pores by electron microscopy. Cell 2000, 100, 265-276. [CrossRef]

15. Mueller, M.; Grauschopf, U.; Maier, T.; Glockshuber, R.; Ban, N. The structure of a cytolytic alpha-helical toxin pore reveals its assembly mechanism. Nature 2009, 459, 726-730. [CrossRef] [PubMed]

16. Peng, W.; de Souza Santos, M.; Li, Y.; Tomchick, D.R.; Orth, K. High-resolution cryo-EM structures of the E. coli hemolysin ClyA oligomers. PLoS ONE 2019, 14, e0213423. [CrossRef] [PubMed]

17. Ganash, M.; Phung, D.; Sedelnikova, S.E.; Lindback, T.; Granum, P.E.; Artymiuk, P.J. Structure of the NheA component of the Nhe toxin from Bacillus cereus: Implications for function. PLOS ONE 2013, 8, e74748. [CrossRef]

18. Madegowda, M.; Eswaramoorthy, S.; Burley, S.K.; Swaminathan, S. X-ray crystal structure of the B component of Hemolysin BL from Bacillus cereus. Proteins 2008, 71, 534-540. [CrossRef]

19. Brauning, B.; Bertosin, E.; Praetorius, F.; Ihling, C.; Schatt, A.; Adler, A.; Richter, K.; Sinz, A.; Dietz, H.; Groll, M. Structure and mechanism of the two-component alpha-helical pore-forming toxin YaxAB. Nat. Commun. 2018, 9, 1806. [CrossRef]

20. Schubert, E.; Vetter, I.R.; Prumbaum, D.; Penczek, P.A.; Raunser, S. Membrane insertion of alpha-xenorhabdolysin in near-atomic detail. eLife 2018, 7. [CrossRef]

21. Jin, T.; Brefo-Mensah, E.; Fan, W.; Zeng, W.; Li, Y.; Zhang, Y.; Palmer, M. Crystal structure of the Streptococcus agalactiae CAMP factor provides insights into its membrane-permeabilizing activity. J. Biol. Chem. 2018, 293, 11867-11877. [CrossRef]

22. Zeng, W.; Ma, H.; Fan, W.; Yang, Y.; Zhang, C.; Arnaud Kombe Kombe, J.; Fan, X.; Zhang, Y.; Dong, Z.; Shen, Z.; et al. Structure determination of CAMP factor of Mobiluncus curtisii and insights into structural dynamics. Int. J. Biol. Macromol. 2020, 150, 1027-1036. [CrossRef]

23. Guo, Q.; Shen, Y.; Lee, Y.S.; Gibbs, C.S.; Mrksich, M.; Tang, W.J. Structural basis for the interaction of Bordetella pertussis adenylyl cyclase toxin with calmodulin. EMBO J. 2005, 24, 3190-3201. [CrossRef]

24. O'Brien, D.P.; Durand, D.; Voegele, A.; Hourdel, V.; Davi, M.; Chamot-Rooke, J.; Vachette, P.; Brier, S.; Ladant, D.; Chenal, A. Calmodulin fishing with a structurally disordered bait triggers CyaA catalysis. PLoS Biol. 2017, 15, e2004486. [CrossRef] [PubMed]

25. Liu, J.; Kozhaya, L.; Torres, V.J.; Unutmaz, D.; Lu, M. Structure-based discovery of a small-molecule inhibitor of methicillinresistant Staphylococcus aureus virulence. J. Biol. Chem. 2020, 295, 5944-5959. [CrossRef] [PubMed]

26. Sugawara, T.; Yamashita, D.; Kato, K.; Peng, Z.; Ueda, J.; Kaneko, J.; Kamio, Y.; Tanaka, Y.; Yao, M. Structural basis for pore-forming mechanism of staphylococcal alpha-hemolysin. Toxicon 2015, 108, 226-231. [CrossRef]

27. Banerjee, A.; Mikhailova, E.; Cheley, S.; Gu, L.Q.; Montoya, M.; Nagaoka, Y.; Gouaux, E.; Bayley, H. Molecular bases of cyclodextrin adapter interactions with engineered protein nanopores. Proc. Natl. Acad. Sci. USA 2010, 107, 8165-8170. [CrossRef] [PubMed] 
28. Song, L.; Hobaugh, M.R.; Shustak, C.; Cheley, S.; Bayley, H.; Gouaux, J.E. Structure of staphylococcal alpha-hemolysin, a heptameric transmembrane pore. Science 1996, 274, 1859-1866. [CrossRef]

29. Yamashita, D.; Sugawara, T.; Takeshita, M.; Kaneko, J.; Kamio, Y.; Tanaka, I.; Tanaka, Y.; Yao, M. Molecular basis of transmembrane beta-barrel formation of staphylococcal pore-forming toxins. Nat. Commun. 2014, 5, 4897. [CrossRef]

30. Nocadello, S.; Minasov, G.; Shuvalova, L.; Dubrovska, I.; Sabini, E.; Bagnoli, F.; Grandi, G.; Anderson, W.F. Crystal structures of the components of the Staphylococcus aureus leukotoxin ED. Acta Crystallogr. Sect. D Struct. Biol. 2016, 72, 113-120. [CrossRef]

31. Savva, C.G.; Fernandes da Costa, S.P.; Bokori-Brown, M.; Naylor, C.E.; Cole, A.R.; Moss, D.S.; Titball, R.W.; Basak, A.K. Molecular architecture and functional analysis of NetB, a pore-forming toxin from Clostridium perfringens. J. Biol. Chem. 2013, 288, 3512-3522. [CrossRef] [PubMed]

32. Huyet, J.; Naylor, C.E.; Savva, C.G.; Gibert, M.; Popoff, M.R.; Basak, A.K. Structural Insights into Clostridium perfringens Delta Toxin Pore Formation. PLoS ONE 2013, 8, e66673. [CrossRef] [PubMed]

33. Olson, R.; Gouaux, E. Crystal structure of the Vibrio cholerae cytolysin (VCC) pro-toxin and its assembly into a heptameric transmembrane pore. J. Mol. Biol. 2005, 350, 997-1016. [CrossRef]

34. Kaus, K.; Lary, J.W.; Cole, J.L.; Olson, R. Glycan specificity of the Vibrio vulnificus hemolysin lectin outlines evolutionary history of membrane targeting by a toxin family. J. Mol. Biol. 2014, 426, 2800-2812. [CrossRef] [PubMed]

35. Justin, N.; Walker, N.; Bullifent, H.L.; Songer, G.; Bueschel, D.M.; Jost, H.; Naylor, C.; Miller, J.; Moss, D.S.; Titball, R.W.; et al. The first strain of Clostridium perfringens isolated from an avian source has an alpha-toxin with divergent structural and kinetic properties. Biochemistry 2002, 41, 6253-6262. [CrossRef] [PubMed]

36. Savva, C.G.; Clark, A.R.; Naylor, C.E.; Popoff, M.R.; Moss, D.S.; Basak, A.K.; Titball, R.W.; Bokori-Brown, M. The pore structure of Clostridium perfringens epsilon toxin. Nat. Commun. 2019, 10, 2641. [CrossRef]

37. Bokori-Brown, M.; Kokkinidou, M.C.; Savva, C.G.; Fernandes da Costa, S.; Naylor, C.E.; Cole, A.R.; Moss, D.S.; Basak, A.K.; Titball, R.W. Clostridium perfringens epsilon toxin H149A mutant as a platform for receptor binding studies. Protein Sci. A Publ. Protein Soc. 2013, 22, 650-659. [CrossRef] [PubMed]

38. Cole, A.R.; Gibert, M.; Popoff, M.; Moss, D.S.; Titball, R.W.; Basak, A.K. Clostridium perfringens epsilon-toxin shows structural similarity to the pore-forming toxin aerolysin. Nat. Struct. Mol. Biol. 2004, 11, 797-798. [CrossRef]

39. Iacovache, I.; De Carlo, S.; Cirauqui, N.; Dal Peraro, M.; van der Goot, F.G.; Zuber, B. Cryo-EM structure of aerolysin variants reveals a novel protein fold and the pore-formation process. Nat. Commun. 2016, 7, 12062. [CrossRef] [PubMed]

40. Degiacomi, M.T.; Iacovache, I.; Pernot, L.; Chami, M.; Kudryashev, M.; Stahlberg, H.; van der Goot, F.G.; Dal Peraro, M. Molecular assembly of the aerolysin pore reveals a swirling membrane-insertion mechanism. Nat. Chem. Biol. 2013, 9, 623-629. [CrossRef] [PubMed]

41. Parker, M.W.; Buckley, J.T.; Postma, J.P.; Tucker, A.D.; Leonard, K.; Pattus, F.; Tsernoglou, D. Structure of the Aeromonas toxin proaerolysin in its water-soluble and membrane-channel states. Nature 1994, 367, 292-295. [CrossRef] [PubMed]

42. Yelland, T.S.; Naylor, C.E.; Bagoban, T.; Savva, C.G.; Moss, D.S.; McClane, B.A.; Blasig, I.E.; Popoff, M.; Basak, A.K. Structure of a C. perfringens enterotoxin mutant in complex with a modified Claudin-2 extracellular loop 2. J. Mol. Biol. 2014, 426, 3134-3147. [CrossRef] [PubMed]

43. Podobnik, M.; Savory, P.; Rojko, N.; Kisovec, M.; Wood, N.; Hambley, R.; Pugh, J.; Wallace, E.J.; McNeill, L.; Bruce, M.; et al. Crystal structure of an invertebrate cytolysin pore reveals unique properties and mechanism of assembly. Nat. Commun. 2016, 7, 11598. [CrossRef] [PubMed]

44. Bokori-Brown, M.; Martin, T.G.; Naylor, C.E.; Basak, A.K.; Titball, R.W.; Savva, C.G. Cryo-EM structure of lysenin pore elucidates membrane insertion by an aerolysin family protein. Nat. Commun. 2016, 7, 11293. [CrossRef]

45. De Colibus, L.; Sonnen, A.F.; Morris, K.J.; Siebert, C.A.; Abrusci, P.; Plitzko, J.; Hodnik, V.; Leippe, M.; Volpi, E.; Anderluh, G.; et al. Structures of lysenin reveal a shared evolutionary origin for pore-forming proteins and its mode of sphingomyelin recognition. Structure 2012, 20, 1498-1507. [CrossRef]

46. Angulo, I.; Acebron, I.; de las Rivas, B.; Munoz, R.; Rodriguez-Crespo, I.; Menendez, M.; Garcia, P.; Tateno, H.; Goldstein, I.J.; Perez-Agote, B.; et al. High-resolution structural insights on the sugar-recognition and fusion tag properties of a versatile beta-trefoil lectin domain from the mushroom Laetiporus sulphureus. Glycobiology 2011, 21, 1349-1361. [CrossRef]

47. Leone, P.; Bebeacua, C.; Opota, O.; Kellenberger, C.; Klaholz, B.; Orlov, I.; Cambillau, C.; Lemaitre, B.; Roussel, A. X-ray and Cryo-electron Microscopy Structures of Monalysin Pore-forming Toxin Reveal Multimerization of the Pro-form. J. Biol. Chem. 2015, 290, 13191-13201. [CrossRef]

48. Rossjohn, J.; Feil, S.C.; McKinstry, W.J.; Tweten, R.K.; Parker, M.W. Structure of a cholesterol-binding, thiol-activated cytolysin and a model of its membrane form. Cell 1997, 89, 685-692. [CrossRef]

49. Xu, L.; Huang, B.; Du, H.; Zhang, X.C.; Xu, J.; Li, X.; Rao, Z. Crystal structure of cytotoxin protein suilysin from Streptococcus suis. Protein Cell 2010, 1, 96-105. [CrossRef]

50. Lawrence, S.L.; Gorman, M.A.; Feil, S.C.; Mulhern, T.D.; Kuiper, M.J.; Ratner, A.J.; Tweten, R.K.; Morton, C.J.; Parker, M.W. Structural Basis for Receptor Recognition by the Human CD59-Responsive Cholesterol-Dependent Cytolysins. Structure 2016, 24, 1488-1498. [CrossRef]

51. Johnson, S.; Brooks, N.J.; Smith, R.A.; Lea, S.M.; Bubeck, D. Structural basis for recognition of the pore-forming toxin intermedilysin by human complement receptor CD59. Cell Rep. 2013, 3, 1369-1377. [CrossRef] 
52. Polekhina, G.; Giddings, K.S.; Tweten, R.K.; Parker, M.W. Insights into the action of the superfamily of cholesterol-dependent cytolysins from studies of intermedilysin. Proc. Natl. Acad. Sci. USA 2005, 102, 600-605. [CrossRef]

53. Koster, S.; van Pee, K.; Hudel, M.; Leustik, M.; Rhinow, D.; Kuhlbrandt, W.; Chakraborty, T.; Yildiz, O. Crystal structure of listeriolysin O reveals molecular details of oligomerization and pore formation. Nat. Commun. 2014, 5, 3690. [CrossRef] [PubMed]

54. Feil, S.C.; Lawrence, S.; Mulhern, T.D.; Holien, J.K.; Hotze, E.M.; Farrand, S.; Tweten, R.K.; Parker, M.W. Structure of the lectin regulatory domain of the cholesterol-dependent cytolysin lectinolysin reveals the basis for its lewis antigen specificity. Structure 2012, 20, 248-258. [CrossRef] [PubMed]

55. Bourdeau, R.W.; Malito, E.; Chenal, A.; Bishop, B.L.; Musch, M.W.; Villereal, M.L.; Chang, E.B.; Mosser, E.M.; Rest, R.F.; Tang, W.J. Cellular functions and X-ray structure of anthrolysin O, a cholesterol-dependent cytolysin secreted by Bacillus anthracis. J. Biol. Chem. 2009, 284, 14645-14656. [CrossRef]

56. Feil, S.C.; Ascher, D.B.; Kuiper, M.J.; Tweten, R.K.; Parker, M.W. Structural studies of Streptococcus pyogenes streptolysin O provide insights into the early steps of membrane penetration. J. Mol. Biol. 2014, 426, 785-792. [CrossRef]

57. van Pee, K.; Neuhaus, A.; D’Imprima, E.; Mills, D.J.; Kuhlbrandt, W.; Yildiz, O. CryoEM structures of membrane pore and prepore complex reveal cytolytic mechanism of Pneumolysin. eLife 2017, 6. [CrossRef]

58. Marshall, J.E.; Faraj, B.H.; Gingras, A.R.; Lonnen, R.; Sheikh, M.A.; El-Mezgueldi, M.; Moody, P.C.; Andrew, P.W.; Wallis, R. The Crystal Structure of Pneumolysin at 2.0 A Resolution Reveals the Molecular Packing of the Pre-pore Complex. Sci. Rep. 2015, 5, 13293. [CrossRef] [PubMed]

59. Lawrence, S.L.; Feil, S.C.; Morton, C.J.; Farrand, A.J.; Mulhern, T.D.; Gorman, M.A.; Wade, K.R.; Tweten, R.K.; Parker, M.W. Crystal structure of Streptococcus pneumoniae pneumolysin provides key insights into early steps of pore formation. Sci. Rep. 2015, 5, 14352. [CrossRef] [PubMed]

60. Rosado, C.J.; Buckle, A.M.; Law, R.H.; Butcher, R.E.; Kan, W.T.; Bird, C.H.; Ung, K.; Browne, K.A.; Baran, K.; BashtannykPuhalovich, T.A.; et al. A common fold mediates vertebrate defense and bacterial attack. Science 2007, 317, 1548-1551. [CrossRef]

61. Xu, Q.; Abdubek, P.; Astakhova, T.; Axelrod, H.L.; Bakolitsa, C.; Cai, X.; Carlton, D.; Chen, C.; Chiu, H.J.; Clayton, T.; et al. Structure of a membrane-attack complex/perforin (MACPF) family protein from the human gut symbiont Bacteroides thetaiotaomicron. Acta Crystallogr. Sect. F Struct. Biol. Cryst. Commun. 2010, 66, 1297-1305. [CrossRef] [PubMed]

62. Cascales, E.; Buchanan, S.K.; Duche, D.; Kleanthous, C.; Lloubes, R.; Postle, K.; Riley, M.; Slatin, S.; Cavard, D. Colicin biology. Microbiol. Mol. Biol. Rev. 2007, 71, 158-229. [CrossRef] [PubMed]

63. Lakey, J.H.; Slatin, S.L. Pore-forming colicins and their relatives. Curr. Top. Microbiol. Immunol. 2001, 257, 131-161. [CrossRef]

64. Pulagam, L.P.; Steinhoff, H.J. Acidic pH-induced membrane insertion of colicin A into E. coli natural lipids probed by site-directed spin labeling. J. Mol. Biol. 2013, 425, 1782-1794. [CrossRef] [PubMed]

65. Ridley, H.; Johnson, C.L.; Lakey, J.H. Interfacial interactions of pore-forming colicins. Adv. Exp. Med. Biol. 2010, 677, 81-90. [CrossRef] [PubMed]

66. Dolejsova, T.; Sokol, A.; Bosak, J.; Smajs, D.; Konopasek, I.; Mikusova, G.; Fiser, R. Colicin U from Shigella boydii Forms Voltage-Dependent Pores. J. Bacteriol. 2019, 201. [CrossRef]

67. Oh, K.J.; Senzel, L.; Collier, R.J.; Finkelstein, A. Translocation of the catalytic domain of diphtheria toxin across planar phospholipid bilayers by its own T domain. Proc. Natl. Acad. Sci. USA 1999, 96, 8467-8470. [CrossRef]

68. Xu, C.; Wang, B.C.; Yu, Z.; Sun, M. Structural insights into Bacillus thuringiensis Cry, Cyt and parasporin toxins. Toxins 2014, 6, 2732-2770. [CrossRef]

69. Barta, M.L.; Dickenson, N.E.; Patil, M.; Keightley, A.; Wyckoff, G.J.; Picking, W.D.; Picking, W.L.; Geisbrecht, B.V. The structures of coiled-coil domains from type III secretion system translocators reveal homology to pore-forming toxins. J. Mol. Biol. 2012, 417, 395-405. [CrossRef]

70. Westphal, D.; Dewson, G.; Czabotar, P.E.; Kluck, R.M. Molecular biology of Bax and Bak activation and action. Biochim. Biophys. Acta 2011, 1813, 521-531. [CrossRef]

71. Hunt, S.; Green, J.; Artymiuk, P.J. Hemolysin E (HlyE, ClyA, SheA) and related toxins. Adv. Exp. Med. Biol. 2010, 677, 116-126. [CrossRef] [PubMed]

72. Brauning, B.; Groll, M. Structural and Mechanistic Features of ClyA-Like alpha-Pore-Forming Toxins. Toxins 2018, 10, 343. [CrossRef]

73. Wilson, J.S.; Churchill-Angus, A.M.; Davies, S.P.; Sedelnikova, S.E.; Tzokov, S.B.; Rafferty, J.B.; Bullough, P.A.; Bisson, C.; Baker, P.J. (Identification and structural analysis of the tripartite alpha-pore forming toxin of Aeromonas hydrophila). Nat. Commun. 2019, 10, 2900. [CrossRef]

74. Fahie, M.; Romano, F.B.; Chisholm, C.; Heuck, A.P.; Zbinden, M.; Chen, M. A non-classical assembly pathway of Escherichia coli pore-forming toxin cytolysin A. J. Biol. Chem. 2013, 288, 31042-31051. [CrossRef]

75. Kristan, K.C.; Viero, G.; Dalla Serra, M.; Macek, P.; Anderluh, G. Molecular mechanism of pore formation by actinoporins. Toxicon 2009, 54, 1125-1134. [CrossRef] [PubMed]

76. Yanagihara, I.; Nakahira, K.; Yamane, T.; Kaieda, S.; Mayanagi, K.; Hamada, D.; Fukui, T.; Ohnishi, K.; Kajiyama, S.; Shimizu, T.; et al. Structure and functional characterization of Vibrio parahaemolyticus thermostable direct hemolysin. J. Biol. Chem. 2010, 285, 16267-16274. [CrossRef]

77. Kundu, N.; Tichkule, S.; Pandit, S.B.; Chattopadhyay, K. Disulphide bond restrains the C-terminal region of thermostable direct hemolysin during folding to promote oligomerization. Biochem. J. 2017, 474, 317-331. [CrossRef] [PubMed] 
78. Baker, M.A.; Rojko, N.; Cronin, B.; Anderluh, G.; Wallace, M.I. Photobleaching reveals heterogeneous stoichiometry for equinatoxin II oligomers. ChemBioChem 2014, 15, 2139-2145. [CrossRef] [PubMed]

79. Mechaly, A.E.; Bellomio, A.; Gil-Carton, D.; Morante, K.; Valle, M.; Gonzalez-Manas, J.M.; Guerin, D.M. Structural insights into the oligomerization and architecture of eukaryotic membrane pore-forming toxins. Structure 2011, 19, 181-191. [CrossRef]

80. Mondal, A.K.; Sreekumar, A.; Kundu, N.; Kathuria, R.; Verma, P.; Gandhi, S.; Chattopadhyay, K. Structural Basis and Functional Implications of the Membrane Pore-Formation Mechanisms of Bacterial Pore-Forming Toxins. Adv. Exp. Med. Biol. 2018, 1112, 281-291. [CrossRef]

81. Linhartova, I.; Bumba, L.; Masin, J.; Basler, M.; Osicka, R.; Kamanova, J.; Prochazkova, K.; Adkins, I.; Hejnova-Holubova, J.; Sadilkova, L.; et al. RTX proteins: A highly diverse family secreted by a common mechanism. FEMS Microbiol. Rev. 2010, 34, 1076-1112. [CrossRef] [PubMed]

82. Kudryashova, E.; Heisler, D.; Zywiec, A.; Kudryashov, D.S. Thermodynamic properties of the effector domains of MARTX toxins suggest their unfolding for translocation across the host membrane. Mol. Microbiol. 2014, 92, 1056-1071. [CrossRef] [PubMed]

83. O'Brien, D.P.; Hernandez, B.; Durand, D.; Hourdel, V.; Sotomayor-Perez, A.C.; Vachette, P.; Ghomi, M.; Chamot-Rooke, J.; Ladant, D.; Brier, S.; et al. Structural models of intrinsically disordered and calcium-bound folded states of a protein adapted for secretion. Sci. Rep. 2015, 5, 14223. [CrossRef] [PubMed]

84. O'Brien, D.P.; Perez, A.C.S.; Karst, J.; Cannella, S.E.; Enguene, V.Y.N.; Hessel, A.; Raoux-Barbot, D.; Voegele, A.; Subrini, O.; Davi, M.; et al. Calcium-dependent disorder-to-order transitions are central to the secretion and folding of the CyaA toxin of Bordetella pertussis, the causative agent of whooping cough. Toxicon 2018, 149, 37-44. [CrossRef]

85. Baumann, U.; Wu, S.; Flaherty, K.M.; McKay, D.B. Three-dimensional structure of the alkaline protease of Pseudomonas aeruginosa: A two-domain protein with a calcium binding parallel beta roll motif. Embo J. 1993, 12, 3357-3364. [CrossRef]

86. Ostolaza, H.; Gonzalez-Bullon, D.; Uribe, K.B.; Martin, C.; Amuategi, J.; Fernandez-Martinez, X. Membrane Permeabilization by Pore-Forming RTX Toxins: What Kind of Lesions Do These Toxins Form? Toxins 2019, 11, 354. [CrossRef] [PubMed]

87. DuMont, A.L.; Yoong, P.; Liu, X.; Day, C.J.; Chumbler, N.M.; James, D.B.; Alonzo, F., 3rd; Bode, N.J.; Lacy, D.B.; Jennings, M.P.; et al. Identification of a crucial residue required for Staphylococcus aureus LukAB cytotoxicity and receptor recognition. Infect. Immun. 2014, 82, 1268-1276. [CrossRef]

88. De, S.; Olson, R. Crystal structure of the Vibrio cholerae cytolysin heptamer reveals common features among disparate poreforming toxins. Proc. Natl. Acad. Sci. USA 2011, 108, 7385-7390. [CrossRef]

89. Unno, H.; Goda, S.; Hatakeyama, T. Hemolytic lectin CEL-III heptamerizes via a large structural transition from alpha-helices to a beta-barrel during the transmembrane pore formation process. J. Biol. Chem. 2014, 289, 12805-12812. [CrossRef]

90. Tweten, R.K.; Hotze, E.M.; Wade, K.R. The Unique Molecular Choreography of Giant Pore Formation by the CholesterolDependent Cytolysins of Gram-Positive Bacteria. Annu. Rev. Microbiol. 2015, 69, 323-340. [CrossRef]

91. Reboul, C.F.; Whisstock, J.C.; Dunstone, M.A. Giant MACPF/CDC pore forming toxins: A class of their own. Biochim. Biophys. Acta 2016, 1858, 475-486. [CrossRef]

92. Johnson, B.B.; Heuck, A.P. Perfringolysin O structure and mechanism of pore formation as a paradigm for cholesterol-dependent cytolysins. Sub Cell. Biochem. 2014, 80, 63-81. [CrossRef]

93. Shannon, J.G.; Ross, C.L.; Koehler, T.M.; Rest, R.F. Characterization of anthrolysin O, the Bacillus anthracis cholesterol-dependent cytolysin. Infect. Immun. 2003, 71, 3183-3189. [CrossRef] [PubMed]

94. Evans, J.C.; Johnstone, B.A.; Lawrence, S.L.; Morton, C.J.; Christie, M.P.; Parker, M.W.; Tweten, R.K. A Key Motif in the Cholesterol-Dependent Cytolysins Reveals a Large Family of Related Proteins. mBio 2020, 11. [CrossRef]

95. Wade, K.R.; Lawrence, S.L.; Farrand, A.J.; Hotze, E.M.; Kuiper, M.J.; Gorman, M.A.; Christie, M.P.; Panjikar, S.; Morton, C.J.; Parker, M.W.; et al. The Structural Basis for a Transition State That Regulates Pore Formation in a Bacterial Toxin. mBio 2019, 10. [CrossRef] [PubMed]

96. van Pee, K.; Mulvihill, E.; Muller, D.J.; Yildiz, O. Unraveling the Pore-Forming Steps of Pneumolysin from Streptococcus pneumoniae. Nano Lett. 2016, 16, 7915-7924. [CrossRef] [PubMed]

97. Leung, C.; Dudkina, N.V.; Lukoyanova, N.; Hodel, A.W.; Farabella, I.; Pandurangan, A.P.; Jahan, N.; Pires Damaso, M.; Osmanovic, D.; Reboul, C.F.; et al. Stepwise visualization of membrane pore formation by suilysin, a bacterial cholesterol-dependent cytolysin. eLife 2014, 3, e04247. [CrossRef]

98. Sato, T.K.; Tweten, R.K.; Johnson, A.E. Disulfide-bond scanning reveals assembly state and beta-strand tilt angle of the PFO beta-barrel. Nat. Chem. Biol. 2013, 9, 383-389. [CrossRef]

99. Czajkowsky, D.M.; Hotze, E.M.; Shao, Z.; Tweten, R.K. Vertical collapse of a cytolysin prepore moves its transmembrane beta-hairpins to the membrane. Embo J. 2004, 23, 3206-3215. [CrossRef]

100. Levan, S.; De, S.; Olson, R. Vibrio cholerae cytolysin recognizes the heptasaccharide core of complex N-glycans with nanomolar affinity. J. Mol. Biol. 2013, 425, 944-957. [CrossRef]

101. Rai, A.K.; Paul, K.; Chattopadhyay, K. Functional mapping of the lectin activity site on the beta-prism domain of vibrio cholerae cytolysin: Implications for the membrane pore-formation mechanism of the toxin. J. Biol. Chem. 2013, 288, 1665-1673. [CrossRef]

102. Zhang, D.; Takahashi, J.; Seno, T.; Tani, Y.; Honda, T. Analysis of receptor for Vibrio cholerae El tor hemolysin with a monoclonal antibody that recognizes glycophorin B of human erythrocyte membrane. Infect. Immun. 1999, 67, 5332-5337. [CrossRef] [PubMed] 
103. Diep, D.B.; Nelson, K.L.; Raja, S.M.; Pleshak, E.N.; Buckley, J.T. Glycosylphosphatidylinositol anchors of membrane glycoproteins are binding determinants for the channel-forming toxin aerolysin. J. Biol. Chem. 1998, 273, 2355-2360. [CrossRef]

104. Hong, Y.; Ohishi, K.; Inoue, N.; Kang, J.Y.; Shime, H.; Horiguchi, Y.; van der Goot, F.G.; Sugimoto, N.; Kinoshita, T. Requirement of N-glycan on GPI-anchored proteins for efficient binding of aerolysin but not Clostridium septicum alpha-toxin. EMBO J. 2002, 21, 5047-5056. [CrossRef]

105. Ivie, S.E.; McClain, M.S. Identification of amino acids important for binding of Clostridium perfringens epsilon toxin to host cells and to HAVCR1. Biochemistry 2012, 51, 7588-7595. [CrossRef]

106. Giddings, K.S.; Zhao, J.; Sims, P.J.; Tweten, R.K. Human CD59 is a receptor for the cholesterol-dependent cytolysin intermedilysin. Nat. Struct. Mol. Biol. 2004, 11, 1173-1178. [CrossRef]

107. Li, Y.; Zeng, W.; Li, Y.; Fan, W.; Ma, H.; Fan, X.; Jiang, J.; Brefo-Mensah, E.; Zhang, Y.; Yang, M.; et al. Structure determination of the CAMP factor of Streptococcus agalactiae with the aid of an MBP tag and insights into membrane-surface attachment. Acta Crystallogr. Sect. D Struct. Biol. 2019, 75, 772-781. [CrossRef] [PubMed]

108. Johnson, C.L.; Ridley, H.; Marchetti, R.; Silipo, A.; Griffin, D.C.; Crawford, L.; Bonev, B.; Molinaro, A.; Lakey, J.H. The antibacterial toxin colicin $\mathrm{N}$ binds to the inner core of lipopolysaccharide and close to its translocator protein. Mol. Microbiol. 2014, 92, 440-452. [CrossRef]

109. Mukherjee, S.; Zheng, H.; Derebe, M.G.; Callenberg, K.M.; Partch, C.L.; Rollins, D.; Propheter, D.C.; Rizo, J.; Grabe, M.; Jiang, Q.X.; et al. Antibacterial membrane attack by a pore-forming intestinal C-type lectin. Nature 2014, 505, 103-107. [CrossRef] [PubMed]

110. Iacovache, I.; Paumard, P.; Scheib, H.; Lesieur, C.; Sakai, N.; Matile, S.; Parker, M.W.; van der Goot, F.G. A rivet model for channel formation by aerolysin-like pore-forming toxins. EMBO J. 2006, 25, 457-466. [CrossRef] [PubMed]

111. Nakai, Y.; Sakurai, Y.; Yamaji, A.; Asou, H.; Umeda, M.; Uyemura, K.; Itoh, K. Lysenin-sphingomyelin binding at the surface of oligodendrocyte lineage cells increases during differentiation in vitro. J. Neurosci. Res. 2000, 62, 521-529. [CrossRef]

112. Zitzer, A.; Westover, E.J.; Covey, D.F.; Palmer, M. Differential interaction of the two cholesterol-dependent, membrane-damaging toxins, streptolysin O and Vibrio cholerae cytolysin, with enantiomeric cholesterol. FEBS Lett. 2003, 553, 229-231. [CrossRef]

113. Rai, A.K.; Chattopadhyay, K. Revisiting the membrane interaction mechanism of a membrane-damaging beta-barrel pore-forming toxin Vibrio cholerae cytolysin. Mol. Microbiol. 2015, 97, 1051-1062. [CrossRef]

114. Lin, Q.; London, E. Altering hydrophobic sequence lengths shows that hydrophobic mismatch controls affinity for ordered lipid domains (rafts) in the multitransmembrane strand protein perfringolysin O. J. Biol. Chem. 2013, 288, 1340-1352. [CrossRef]

115. Kozorog, M.; Sani, M.A.; Lenarcic Zivkovic, M.; Ilc, G.; Hodnik, V.; Separovic, F.; Plavec, J.; Anderluh, G. (19)F NMR studies provide insights into lipid membrane interactions of listeriolysin $\mathrm{O}$, a pore forming toxin from Listeria monocytogenes. Sci. Rep. 2018, 8, 6894. [CrossRef]

116. Farrand, A.J.; Hotze, E.M.; Sato, T.K.; Wade, K.R.; Wimley, W.C.; Johnson, A.E.; Tweten, R.K. The Cholesterol-dependent Cytolysin Membrane-binding Interface Discriminates Lipid Environments of Cholesterol to Support beta-Barrel Pore Insertion. J. Biol. Chem. 2015, 290, 17733-17744. [CrossRef]

117. Dowd, K.J.; Farrand, A.J.; Tweten, R.K. The cholesterol-dependent cytolysin signature motif: A critical element in the allosteric pathway that couples membrane binding to pore assembly. PLoS Pathog. 2012, 8, e1002787. [CrossRef]

118. Farrand, A.J.; LaChapelle, S.; Hotze, E.M.; Johnson, A.E.; Tweten, R.K. Only two amino acids are essential for cytolytic toxin recognition of cholesterol at the membrane surface. Proc. Natl. Acad. Sci. USA 2010, 107, 4341-4346. [CrossRef] [PubMed]

119. Wilke, G.A.; Bubeck Wardenburg, J. Role of a disintegrin and metalloprotease 10 in Staphylococcus aureus alpha-hemolysinmediated cellular injury. Proc. Natl. Acad. Sci. USA 2010, 107, 13473-13478. [CrossRef] [PubMed]

120. Spaan, A.N.; Henry, T.; van Rooijen, W.J.M.; Perret, M.; Badiou, C.; Aerts, P.C.; Kemmink, J.; de Haas, C.J.C.; van Kessel, K.P.M.; Vandenesch, F.; et al. The staphylococcal toxin Panton-Valentine Leukocidin targets human C5a receptors. Cell Host Microbe 2013, 13, 584-594. [CrossRef] [PubMed]

121. Bruggisser, J.; Tarek, B.; Wyder, M.; Muller, P.; von Ballmoos, C.; Witz, G.; Enzmann, G.; Deutsch, U.; Engelhardt, B.; Posthaus, H. CD31 (PECAM-1) Serves as the Endothelial Cell-Specific Receptor of Clostridium perfringens beta-Toxin. Cell Host Microbe 2020, 28, 69-78 e66. [CrossRef]

122. Zilnyte, M.; Venclovas, C.; Zvirbliene, A.; Pleckaityte, M. The cytolytic activity of vaginolysin strictly depends on cholesterol and is potentiated by human CD59. Toxins 2015, 7, 110-128. [CrossRef]

123. Dong, J.; Qiu, J.; Zhang, Y.; Lu, C.; Dai, X.; Wang, J.; Li, H.; Wang, X.; Tan, W.; Luo, M.; et al. Oroxylin A inhibits hemolysis via hindering the self-assembly of alpha-hemolysin heptameric transmembrane pore. PLoS Comput. Biol. 2013, 9, e1002869. [CrossRef] [PubMed]

124. Vivekananda, J.; Salgado, C.; Millenbaugh, N.J. DNA aptamers as a novel approach to neutralize Staphylococcus aureus alpha-toxin. Biochem. Biophys. Res. Commun. 2014, 444, 433-438. [CrossRef] [PubMed]

125. Li, G.; Shen, X.; Wei, Y.; Si, X.; Deng, X.; Wang, J. Quercetin reduces Streptococcus suis virulence by inhibiting suilysin activity and inflammation. Int. Immunopharmacol. 2019, 69, 71-78. [CrossRef] [PubMed]

126. Wu, Q.; Guo, Z. Glycosylphosphatidylinositols are potential targets for the development of novel inhibitors for aerolysin-type of pore-forming bacterial toxins. Med. Res. Rev. 2010, 30, 258-269. [CrossRef] 
127. Ortines, R.V.; Liu, H.; Cheng, L.I.; Cohen, T.S.; Lawlor, H.; Gami, A.; Wang, Y.; Dillen, C.A.; Archer, N.K.; Miller, R.J.; et al. Neutralizing Alpha-Toxin Accelerates Healing of Staphylococcus aureus-Infected Wounds in Nondiabetic and Diabetic Mice. Antimicrob. Agents Chemother. 2018, 62. [CrossRef]

128. Alonzo, F., 3rd; Kozhaya, L.; Rawlings, S.A.; Reyes-Robles, T.; DuMont, A.L.; Myszka, D.G.; Landau, N.R.; Unutmaz, D.; Torres, V. CCR5 is a receptor for Staphylococcus aureus leukotoxin ED. Nature 2013, 493, 51-55.

129. Schwiering, M.; Husmann, M.; Hellmann, N. P2X-Receptor Antagonists Inhibit the Interaction of S. aureus Hemolysin A with Membranes. Toxins 2017, 9, 332. [CrossRef]

130. Fernandes da Costa, S.P.; Savva, C.G.; Bokori-Brown, M.; Naylor, C.E.; Moss, D.S.; Basak, A.K.; Titball, R.W. Identification of a key residue for oligomerisation and pore-formation of Clostridium perfringens NetB. Toxins 2014, 6, 1049-1061. [CrossRef]

131. Bokori-Brown, M.; Hall, C.A.; Vance, C.; Fernandes da Costa, S.P.; Savva, C.G.; Naylor, C.E.; Cole, A.R.; Basak, A.K.; Moss, D.S.; Titball, R.W. Clostridium perfringens epsilon toxin mutant Y30A-Y196A as a recombinant vaccine candidate against enterotoxemia. Vaccine 2014, 32, 2682-2687. [CrossRef]

132. Lohith, G.K.; Kingston, J.J.; Singh, A.K.; Murali, H.S.; Batra, H.V. Evaluation of recombinant leukocidin domain of VvhA exotoxin of Vibrio vulnificus as an effective toxoid in mouse model. Immunol. Lett. 2015, 167, 47-53. [CrossRef] [PubMed]

133. Cockeran, R.; Steel, H.C.; Theron, A.J.; Mitchell, T.J.; Feldman, C.; Anderson, R. Characterization of the interactions of the pneumolysoid, Delta6 PLY, with human neutrophils in vitro. Vaccine 2011, 29, 8780-8782. [CrossRef] [PubMed]

134. Douce, G.; Ross, K.; Cowan, G.; Ma, J.; Mitchell, T.J. Novel mucosal vaccines generated by genetic conjugation of heterologous proteins to pneumolysin (PLY) from Streptococcus pneumoniae. Vaccine 2010, 28, 3231-3237. [CrossRef] [PubMed]

135. Mann, B.; Thornton, J.; Heath, R.; Wade, K.R.; Tweten, R.K.; Gao, G.; El Kasmi, K.; Jordan, J.B.; Mitrea, D.M.; Kriwacki, R.; et al. Broadly protective protein-based pneumococcal vaccine composed of pneumolysin toxoid-CbpA peptide recombinant fusion protein. J. Infect. Dis. 2014, 209, 1116-1125. [CrossRef] [PubMed]

136. Hu, C.M.; Zhang, L. Nanotoxoid Vaccines. Nano Today 2014, 9, 401-404. [CrossRef]

137. Koo, J.; Escajadillo, T.; Zhang, L.; Nizet, V.; Lawrence, S.M. Erythrocyte-Coated Nanoparticles Block Cytotoxic Effects of Group B Streptococcus beta-Hemolysin/Cytolysin. Front. Pediatr. 2019, 7, 410. [CrossRef]

138. Narva, K.E.; Wang, N.X.; Herman, R. Safety considerations derived from Cry34Ab1/Cry35Ab1 structure and function. J. Invertebr. Pathol. 2017, 142, 27-33. [CrossRef]

139. Dhillon, S. Correction to: Moxetumomab Pasudotox: First Global Approval. Drugs 2019, 79, 105. [CrossRef] 